\title{
NATUURWETENSCHAPPELIJKE BELANGSTELLING VOOR DE NEDERLANDSE ANTILLEN
}

\author{
DOOR \\ P. Wagenaar Hummelinck \\ (Zoölogisch Laboratorium, Utrecht)
}

De tijd schijnt voorbij, dat een openlijke getuigenis over de misdeeldheid van de Nederlandse Antillen door ,Moeder Natuur” vrijwel algemene instemming vond. De bodem, vroeger wel een zeer weinig aantrekkelijk object, is - nadat men iets van zijn bouw heeft leren kennen en zijn rol in de waterhuishouding heeft moeten bestuderen - thans voor velen een levend begrip geworden, dat sommigen, met zijn processen van opbouw en afbraak, voortdurend bezig houdt. De plantenwereld kreeg steeds meer kenners, en de dierenwereld bleek rijker en merkwaardiger te zijn dan men vroeger had durven dromen.

Tientallen trekken er nu Zaterdags en Zondags op uit, omdat zij maar niet genoeg kunnen krijgen van het wonderlijke en kleurige leven tussen de riffen, of tussen de mangrovewortels in de stille binnenwateren. En steeds meer mensen voelen zich door de Christoffel aangetrokken, niet om het bereiken van de top alleen, maar ook om de botanische pracht. Vroeger wist een enkeling te verhalen van een grote grot op Hato die geen einde nam, en van indianentekeningen op Aruba en Bonaire; thans hebben velen deze grot tot in zijn verste uithoeken verkend, zijn nog vele andere grotten onderzocht en in kaart gebracht, en blijken er niet alleen op Aruba en Bonaire, maar ook op Curaçao op verschillende plaatsen rotstekeningen voor te komen.

Toch zijn er nog maar weinig onderzoekers geweest, die in de bestudering van de bodem en van de planten- en dierenwereld van deze eilanden een belangrijke levenstaak vonden. Het vasteland van Zuid-Amerika, met zijn machtige gebergten, uitgestrekte oerwouden, indrukwekkend plantenkleed en merkwaardige dierenwereld trok veel meer de aandacht. De prachtige en gevarieerde kust van de Nederlandse eilanden was slechts 
een deel van de grote verscheidenheid van Caraïbische kustvormen. En zo kregen onze Antillen van de meeste natuuronderzoekers die hen bezochten slechts een voorbijgaande belangstelling. Slechts enkelen drongen dieper door in het wezen der eilanden en schonken hen blijvend hun aandacht en genegenheid.

Het wetenschappelijk onderzoek.

De planten- en dierenlijsten, welke in de bekende werkjes van Teenstra, 1836, en Simons, 1868, te vinden zijn, getuigen reeds van een opmerkelijke natuurhistorische belangstelling. Hun wetenschappelijke waarde is echter gering, hoe uitgebreid de opsommingen ook mogen zijn. Hetzelfde geldt voor het plantkundeboekje van HurTado, dat in 1891 op Curaçao het licht zag.

Ondertussen was de ontdekking van goud op Aruba, in 1824, reeds de aanleiding geweest tot het e e r s t e, w e t e n s c h a ppelijk verantwoorde geologisch-mineralogische onderzoek van de Benedenwindse Eilanden. Oberbergrath Stiff, uit Nassau in Duitsland, door de Nederlandse Regering hiermede belast, had zijn rapporten in 1827 ingediend, terwijl in hetzelfde jaar REINWARDT enkele mededelingen over ,eene kleine verzameling van steenen, delfstoffen en rotssoorten" van Aruba had gedaan. De Zweed Cleve zorgde in 1871 voor de eerste geologische opneming van de Bovenwinden.

MARTIN en Suringar, hoogleraren in Leiden, waren de leiders van de ,Nederlandsche West-Indische Wetenschappelijke Expeditie 1884-1885". MARTIN werd de grote pionier van de geologie van de Nederlandse Antillen, hoewel hij maar 46 dagen op de eilanden verbleef. Zijn reisbeschrijving - in het eerste deel van zijn Bericht über eine Reise nach Niederländisch West-Indien is een boek, dat thans stellig nog door een ieder, die in onze West belang stelt, met genoegen zal worden gelezen.

MARTIN bezocht alleen de Benedenwinden; zijn leerling, de student G. A. F. Molengraaff óók de Bovenwinden. De eerste publicatie van de latere professor MolengraAfF, die zich evenals zijn leermeester - ontwikkelde tot een veelzijdig geoloog van wereldnaam, was een uitvoerig proefschrift over De geologie van het eiland St. Eustatius; de laatste publicatie een waardevol overzicht van de geologie van de Nederlandse Bovenwindse Eilanden, in de Feestbundel welke in 1931, ter ere van de 80jarige MARTIN, werd uitgegeven. 
Prof. SURINGAR werd op deze reis dermate door de vormenrijkdom der melocactussen geboeid, dat hij hieraan veertien jaar achtereen, tot het einde van zijn leven, bleef doorwerken. Uit zijn studies, en die van zijn zoon Valckenier Suringar, krijgen wij van Aruba en Curaçao de indruk als te zijn een soort scheppingscentrum van merkwaardige plantenvormen. De student van BREDA DE HAAN, die Suringar hielp bij het verzamelen, schreef later een proefschrift over de anatomie van dit plantengeslacht.

De Leidse entomoloog J. R. H. Neervoort van de Poll verzamelde vooral insecten. De publicaties van vaN HASSELT, over de door VAN DE POLL verzamelde spinnen, en die van SnEllen, over een vlindercollectie welke door pater Alph. JANSEN tussen 1875 en 1880 op Curaçao was verzameld, zijn de eerste zoölogische bewerkingen van belang, en tot op heden de enige die wij van deze opvallende diergroepen bezitten. VAN LIDTH DE JEUDE schreef vooral over reptielen, een diergroep waaraan in later tijd, ook door buitenlanders, nog veel aandacht is besteed.

HARTERT, uit Engeland, bezocht in 1892 de eilanden voor zijn ornithologische studies.

Verschillende deskundigen werden in de eerste jaren van deze eeuw uitgezonden om Curaçao's natuurlijke welvaartsbronnen nader te bestuderen en hun opbrengst zo mogelijk te vergroten. Een van de eerste was de Utrechtse botanicus prof. WENT, die in 1901 een land- en tuinbouwkundig rapport uitbracht. Een andere bekende figuur uit die tijd was de landbouwkundige RIJKENS, op wiens publicaties, door vele voorstanders van een bevordering van de landbouw en veeteelt op de Benedenwinden, nog steeds wordt gewezen.

De latere hoogleraar BoEKE, de histoloog uit Utrecht, maakte in 1904-1905, als visserijdeskundige, een reis naar de Nederlandse Antillen. Zijn Rapport betreffende .... de visscherij en de industrie van zeeproducten in de Kolonie Curaçao is nog steeds de enige fundamentele studie, welke wij op dit gebied bezitten. BoeKE's grote collectie vissen werd, in 1919, door MetzelaAR in diens proefschrift beschreven; het is nog steeds hèt standaardwerk, dat wij over de vissen van de Nederlandse eilanden bezitten.

In 1909 publiceerde de Amerikaan CORY een verhandeling over vogels van de Benedenwindse Eilanden, welke door verschillende personen waren verzameld. 
BolDINGH, toentertijd conservator aan de Utrechtse Universiteit, deed, na een bezoek aan de Nederlandse Bovenwinden in 1905, een F 1 o r a van deze eilanden als proefschrift het licht zien. Na een studiereis naar de Benedenwinden, in 1909-1910, volgde een zelfde soort werk over dit gebied. Hij geeft hierin ook een opsomming van de activiteit van vroegere plantenverzamelaars. Met zijn bekende Flora voor de Nederlandsch WestIndische Eilanden - goed pionierswerk, maar niet gemakkelijk te gebruiken en bovendien thans verouderd - moet iedereen die zich voor de plantenwereld van onze eilanden interesseert zich thans, na bijna veertig jaar, nòg tevreden stellen.

In dezelfde tijd, van 1906-1912, werden door kapitein L. Lens en zijn medewerkers J. V. D. Werbata en W. A. JonckHEER JR, de prachtige Topographische kaart van Curaçao, Aruba en Bonaire 1: 20.000 opgenomen, en ook die van St. Maarten en St. Eustatius vervaardigd. Aan een herziening is men nog niet toegekomen, wanneer wij de enigszins gereviseerde, fotografische reproducties van U.S. Army buiten beschouwing laten. Alles wacht nu op het tot stand komen van de luchtfotogrammetrische kaart, waarvoor de nodige gelden echter nog steeds niet zijn gevoteerd. De foto's van Curaçao, Aruba en Bonaire zijn reeds enkele jaren geleden genomen.

In 1914 schreef Vernhout over de merkwaardige slakkenfauna van de Benedenwindse Eilanden, terwijl in hetzelfde jaar door de Amerikaan BARBour de gegevens over de reptielen en amphibieën van de Bovenwinden werden samengevat.

In de Encyclopaedie van Nederlandsch West-Indië vinden wij de stand van onze kennis van de Nederlandse Antillen tot op 1914 op verdienstelijke wijze weergegeven. Met de voorbereiding van een nieuwe uitgave - al sinds jaren een hartewens van velen die in onze West belangstellen - is men dit jaar begonnen, zodat wij mogen verwachten, dat over enkele jaren een nieuwe bron van informatie op biologisch en geologisch gebied ter beschikking zal staan.

De verzamelreis welke, in 1920, door de toenmalige conservator aan het Zoölogisch Museum te Amsterdam, VAN DER HoRst - thans hoogleraar te Johannesburg - werd ondernomen, kan worden beschouwd als het begin van het s y s t ematisch opgezette, faunistische onderzoek van onze eilanden. Hij beperkte zich daarbij in hoofdzaak tot de zee-fauna van de Caracas-Baai en het Spaanse Water. Vele 
belangrijke Bijdragen tot de kennis der fauna van Curaçao waren het resultaat.

Een kennismaking met het Curaçaose landschap van enkele uren, in 1920, was voor de Amerikaanse malacoloog BAKER aanleiding tot een meer langdurig bezoek aan de ABC-eilanden in 1922. Hij maakte een diepgaande studie van de Land and freshwater molluscs of the Dutch Leeward Islands en was de eerste, die wees op de belangrijkheid van het voor de Benedenwinden kenmerkende fauna-element. Ook het artikel van WERNER waarin materiaal wordt beschreven dat in 1922-1925 door de Oostenrijker GABRIEL, toentertijd gouvernements-arts, op Bonaire was verzameld - bevat belangwekkende zoögeografische gevolgtrekkingen. Veel later - toen hij alweer in Perzië rondzwierf - wijdde GABRIEL een boekje aan de „sjogógo”, dat zijn waarde vooral ontleent aan de foto's van de broedplaatsen van de flamingo's op Bonaire.

De Duitser WinkLer publiceerde in 1926 een geografische compilatie welke onze eilanden tot onderwerp had.

In 1921 werd de mijningenieur G. J. H. MolengraafF uitgezonden om een onderzoek in te stellen naar de geologische gesteldheid van Curaçao en het voorkomen van grondwater. Zijn proefschrift over de Geologie en geohydrologie van het eiland Curaçao leidde in 1929 het modern geologische onderzoek in, dat door prof. RutTen en diens leerlingen werd voortgezet.

Nadat er vele avondcollege's aan de Antillen en het omgevende gebied waren gewijd, vertrok de „Utrechtsche Antillen Excursie 1930" naar het terrein van studie. Van 14 April tot 4 Mei kampeerde men in West-Curaçao, van 10 Mei tot 10 Juni trok men door Aruba, en van 16 Juni tot 9 Augustus was men op Bonaire. Proefschriften over The geology of Aruba, van Westermann, en de Geology and paleontology of Bonaire, van PIJPERS, benevens een aantal kleinere publicaties waren het resultaat. De leider schreef spoedig na terugkomst een reisverhaal en een geologische geschiedenis van onze Benedenwindse Eilanden, welke zich prettig laten lezen.

Op deze reis verzamelde WESTERMANn een aantal bodemmonsters waarvan de bewerking, door HamiltoN, in 1945, verscheen. Door Vermunt werden ook vogels verzameld, waarover gegevens met vele veldwaarnemingen door RUTTEN JR werden gepubliceerd. De hobby van MAcGILlavRY was het verzamelen van insecten en WAGENAAR HUMMELINCK wijdde zijn 
aandacht aan de dierenwereld, vooral van Bonaire, gedurende de drie maanden die hij op dit eiland achterbleef. In de Zoologische Ergebnisse einer Reiss nach Bonaire, Curaçao und Aruba, welke in 1933 en volgende jaren verschenen, vindt men vele gegevens over de dierenwereld van de zee en van de zoete en zoute binnenwateren.

Van eind Augustus 1936 tot begin April 1937 werd door Hummelinck de land- en zoetwaterfauna van de Benedenwinden nader onderzocht, en in omstreeks dezelfde periode, maar twaalf jaar later, in het bijzonder ook nog eens de zeefauna. De resultaten van deze onderzoekingen verschijnen in de Studie son the fauna of Curaçao, Aruba, Bonaire and the Venezuelan islands, een seriewerk, waarvan het eerste deel in 1940 werd uitgegeven. Het dierkundig onderzoek van de Nederlandse Bovenwinden en naburige eilanden kon pas in Mei, Juni en Juli 1949 ernstig ter hand worden genomen.

Als resultaten van deze reizen op botanisch gebied moge hier alleen de artikelen over agaven en cactussen van HummeLINCK en over de blauwalgen van FRÉmY worden genoemd. Van de grassen van de verzameling van BoLDINGH verscheen in 1945 een nieuwe bewerking van de hand van mej. Amshoff.

Ook van de zijde der pharmaceuten ondervonden de eilanden belangstelling, getuige de dissertaties van mej. MEIJER, in 1932, over enkele volksgeneeskruiden, en van HARDERS, in 1940, over de Curaçao-aloë. Vijf jaren later werd, in opdracht van het Curaçaose Gouvernement, door twee Curaçaose ingezetenen aan de aloë nog een uitvoerige studie gewijd, en ook in latere jaren is deze nuttige plant nog herhaaldelijk in de literatuur ter sprake gekomen. Het spreekt vanzelf, dat de Afdeling Tropische Producten van het Indisch Instituut te Amsterdam zich voor deze en andere op haar gebied liggende zaken bijzonder interesseert.

Een overzicht van onze kennis van Het klimaat van Nederlandsch West-Indie werd reeds in 1935 vanwege het Koninklijk Nederlandsch Meteorologisch Instituut uitgegeven. Belangwekkende beschouwingen over de regenval gaf VISSER als bijlage van het rapport-KRUL over De waterhuishouding van Curaçao en Aruba dat in 1949 verscheen. Bekend is dit rapport echter vooral om zijn beschouwingen en gevolgtrekkingen op hydrologisch en landbouwkundig gebied.

In December 1949 kwam het zeer uitvoerige en van een complete bibliografie voorziene Overzicht van de geologische en mijnbouwkundige kennis der Nederlandse Antillen, benevens 
voorstellen tot verdere exploratie van de pers; een werkje waarvoor zowel geologen als algemeen-belangstellenden WESTERMANN en het Indisch Instituut wel dankbaar mogen zijn. Er wordt hierin de nadruk gelegd op het vele dat wij — ondanks het goede werk dat er reeds is verricht - nog niet weten. Hierop hebben trouwens de resultaten van de water-diepboring op Aruba, in 1942, en de boringen op Hato - waarover binnenkort uitvoerige studies mogen worden verwacht - en de waarnemingen van de Zwitser Schaub reeds gewezen. Van groot belang is voorts de, door de Amerikaan R. A. Christman in 1948 en 1949 uitgevoerde geologische kaartering van St. Maarten, welker resultaten in de naaste toekomst zullen worden gepubliceerd.

Het is vooral frater Realino Janssen geweest, die gedurende vele jaren de plaatselijke belangstelling voor $\mathrm{de} \mathrm{n}$ a t u u r levendig heeft gehouden. De eerste uitgave van zijn boekje over Aardrijkskunde, in 1929, was een belangrijke gebeurtenis, hoewel dit reeds, twintig jaar terug, in het boekje van Nijman een voorganger had gehad. De 2e druk in 1931 en de $3 e$ in 1938 getuigen van de toeneming van onze kennis in deze jaren. Zijn Plantkunde van Curaçao voor M.U.L.O. kon eerst in 1947 herdrukt worden, nadat de eerste oplage van 1935 al sinds jaren was uitverkocht. Van het thans opgeheven schoolmuseum van het St. Thomas-College was hij geruime tijd de beheerder.

In de laatste tijd treft ons het belangrijke botaniseerwerk van frater ARNOLDO BROEDERS op verschillenden eilanden, bedoeld als voorbereiding van een nieuwe, geillustreerde Flora, waaraan - naar wij hopen - binnenkort in Utrecht zal kunnen worden begonnen. Frater ARNOLDO is bovendien bezig aan een boekje over de nuttige planten van de Nederlandse Antillen.

Op enkele lagere scholen heeft de handleiding welke frater AndReas Corsini in 1945 in het licht gaf, bij de dierkundelessen goede diensten bewezen.

Een bekende figuur op ornithologisch gebied was korporaalseiner DE JONG, die, onder de schuilnaam Vogelvriend, tussen 1940 en 1945 tientallen artikeltjes schreef in de „Beurs- en Nieuwsberichten" en andere Curaçaose bladen. Meer wetenschappelijk, hoewel voor de bevolking van geringere betekenis, is de belangstelling van PHELPS, vader en zoon, uit Caracas, die in 1947 een kort bezoek aan Bonaire brachten, in verband met hun uitvoerige studies over de Venezolaanse vogelwereld. 
Voor onze Bovenwinden is het, in 1939 verschenen artikel van de Amerikaan Danforth - die in 1937 twaalf dagen op Saba doorbracht - nog steeds de enige vogelstudie van betekenis. KRUYTHOFF toont grote belangstelling te hebben voor flora, fauna en geologie van de Bovenwinden, maar zijn in 1938 verschenen boekje geeft weinig nieuws.

Ook op het gespecialiseerde natuurwetenschappelijke werk van de patholoog-anatoom HARTz, de bacterioloog POT en andere Curaçaose medici moge hier de aandacht worden gevestigd.

Toen pater BRENNEKER - thans pastoor op Curaçao - nog Bonaire als standplaats had, deed hij pionierswerk op het gebied van de onderwaterfotografie. Hij schreef, onder de naam Frans van Venlo, vele schetsjes in de "Amigoe di Curaçao" en is thans nog steeds een vurig propagandist voor de schoonheid van het leven onder het zeeoppervlak. Zijn platenboek, dat in November 1950 van de pers kwam, was een verrassing door de mooie onderwaterfoto's welke het bevatte, maar een teleurstelling omdat er nog zooveel meer van te maken zou zijn geweest. Ook door het boek van de Oostenrijkse student Hass, Unter Korallen und Haien - waarin op wel wat kwajongensachtige maar toch onderhoudende wijze, en aan de hand van prachtige foto's, wordt verteld van jachten onder water met camera en speer - is deze onbekende wereld van Bonaire en Curaçao in de belangstelling van menig natuurliefhebber gekomen.

Op 29 Augustus 1945 werd d e $\mathrm{n}$ a t u u r w e t e n s c h a ppelijke belangstelling voor de Nederlandse Antillen

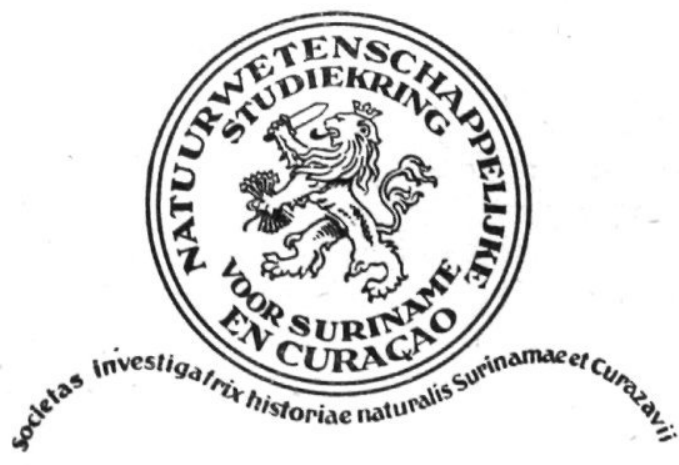
$\mathrm{g}$ e or $\mathrm{g}$ a $\mathrm{n}$ is e e r d in de ,Natuurwetenschappelijke Studiekring voor Suriname en Curaçao", gevestigd te Utrecht. De activiteit van de ,Studiekring" ten aanzien van de Nederlandse Antillen blijkt o.m. uit enkele publicaties en wordt bovendien vrij uitvoerig besproken in de krantenverslagen van de 10e en de $12 \mathrm{e}$ ledenvergadering, welke op 7 Januari en 9 September 
1949 op Curaçao werden gehouden. Niet alleen het onderzoek van bodem, plantendek en dierenwereld heeft de volle belangstelling van de leden, maar ook de heemkunde, de natuurbescherming, en andere zaken welke met een evenwichtige samenleving van de mens op onze eilanden ten nauwste verband houden.

In Willemstad werd op 27 December 1948 een ,NNatuurwetenschappelijke Werkgroep Nederlandse Antillen” opgericht, welke tijdens haar nog zo korte bestaan reeds verschillende openbare bijeenkomsten en excursie's heeft gehouden; niet alleen op Curaçao, maar ook op Aruba en Bonaire. De werkzaamheid concentreerde zich tot nu toe op onderwerpen, welke reeds tevoren min of meer in de belangstelling van de leden lagen, zoals botanische studies (fr. ARNOLDO), het verzamelen van dieren $(\mathrm{J} . \mathrm{G}$.

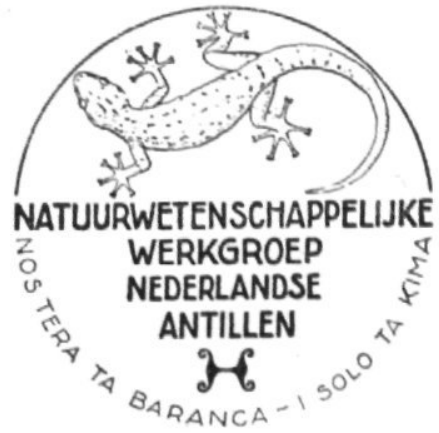
DE Jong en J. van ZIJL), onderwaterfotografie (p. VITUS BRENNEKER), museumwerk (fr. Realino en mevr. M. DiemontKoITER), en het exploreren van de talrijke grotten (A. D. RINGMA) met daarbij het zoeken naar rotstekeningen en andere resten van Indiaanse cultuur.

Het spreekt welhaast vanzelf dat de ,Werkgroep” nauw samenwerkt met de "Studiekring”, op wiens terrein zij zich in hoofdzaak beweegt. Natuurlijk wordt ook samenwerking gezocht met de Stichting „Het Curaçaosche Museum” en met iedere organisatie welke de natuur op de Nederlandse Antillen ter harte gaat.

Een naturwetenschappelijk museum.

Het C uraçaose m u se um werd op 7 Maart 1948 feestelijk geopend. Het is een voormalig militair hospitaal en quarantainegebouw, dat door een zorgvuldige restauratie en na het aanbrengen van de nodige veranderingen, in een aantrekkelijk museumgebouw, is herschapen (fig. 1 en 9).

De belangrijkste drijfveer voor de oprichting was wel het verlangen, om nog zoveel mogelijk van de typische cultuuruitingen der Nederlandse Antillen, welke dreigden te verdwijnen, op gepaste wijze bijeen te brengen, te bewaren en aan belangstellenden te tonen. Ook wilde men het gevoel voor de 
beeldende kunst bij de bevolking wakker roepen - en ten slotte werd er een natuurhistorische afdeling aan verbonden, welke vooral ten doel heeft de belangstelling voor de natuur te wekken, door de bezoekers dingen uit eigen omgeving te laten zien, waarvan de betekenis en de schoonheid hun anders verborgen zouden blijven.

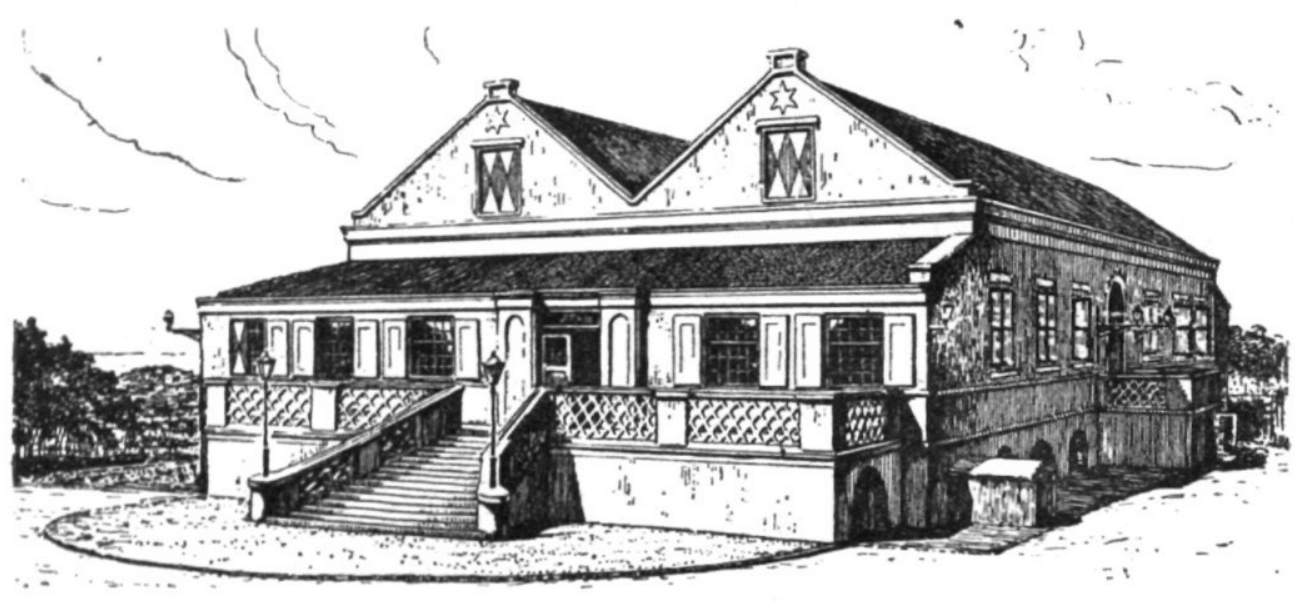

Fig. 1. Het Curaçaose Museum: een voormalig militair hospitaal dat door een zorgvuldige restauratie in een aantrekkelijk museumgebouw werd herschapen. (Naar een foto getekend door J. PRIJS).

„Het Curaçaosche Museum” is dus een typisch regionaal museum, waar in het algemeen alléén dingen worden tentoongesteld, die betrekking hebben op de Nederlandse Antillen. Een uitzondering hierop vinden wij bij de afdeling beeldende kunst, - waar - onder leiding van de veelzijdig begaafde kinderarts CHR. J. H. ENGELS, oprichter van het Museum en voorzitter van de Regentenraad - geregeld tentoonstellingen worden gehouden, die tevens tot doel hebben de stichting als geheel in de publieke belangstelling te brengen.

Een brede trap leidt, over een ruime stoep, naar de hoofdingang, waardoor men komt in een lange booggang met bovenlicht, die toegang geeft tot de vier zalen der bovenverdieping (fig. 2): de Curaçaose zaal, de meubelzaal, de industrie- en kaartenzaal en de schilderijenzaal. Door de laatste komt men in een erker, de bibliotheek. Door de Curaçaose keuken bereikt men verder een open galerij, met uitzicht op de cactustuin langs de Van Leeuwenhoekstraat, waaraan de hoofdingang tot de museumtuin is gelegen. - Bij de erker gaat er een trap naar beueden. 


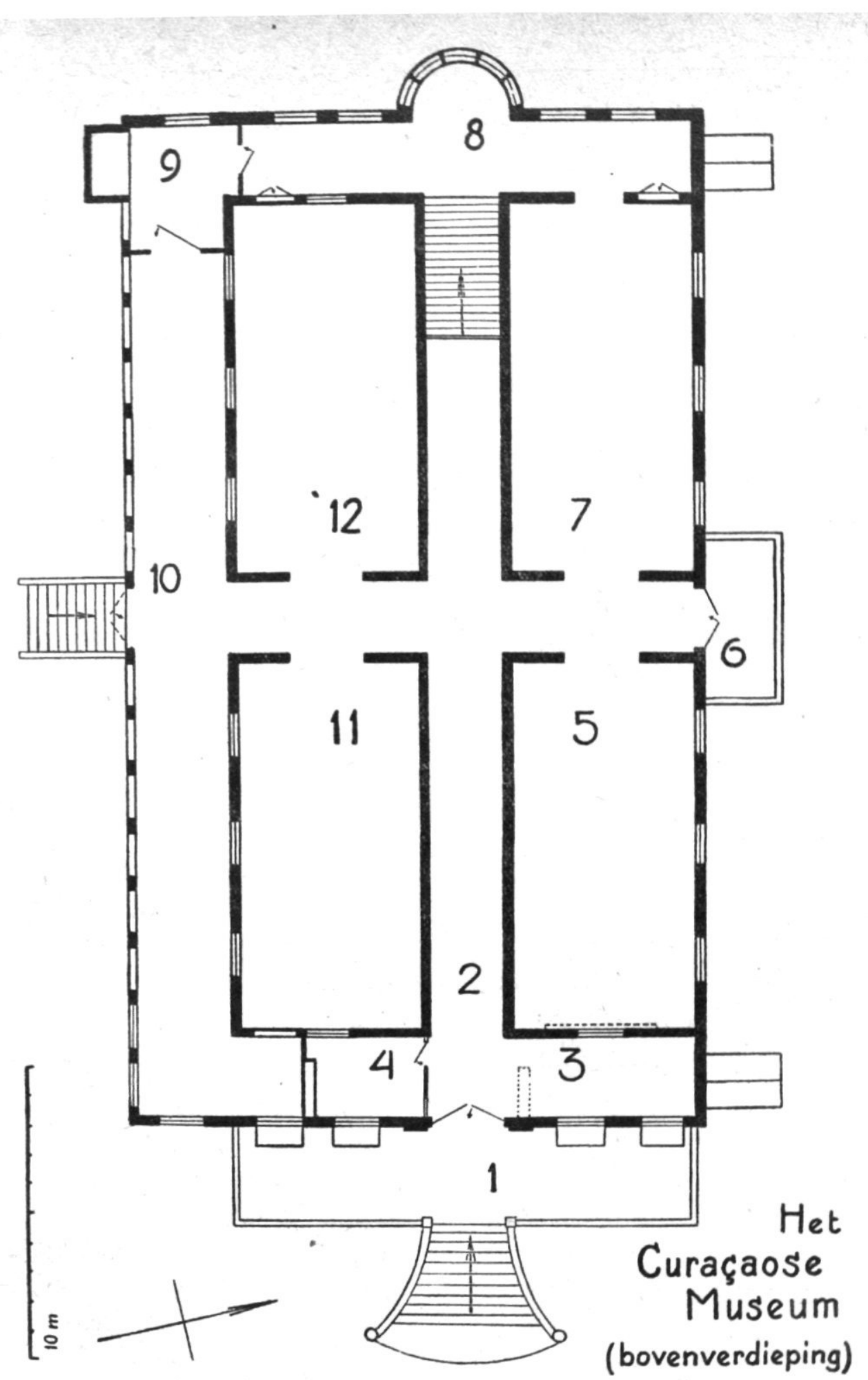

Fig. 2. Plattegrond van de bovenverdieping van het Curaçaose Museum 1 "Stoep". 2 Booggang met bovenlicht. 3 Vestiaire. 4 Directiekamertje. 5 Industrie- en kaartenzaal. 6 Balcon. 7 Schilderijenzaal. 8 Bibliotheek. 9 Curaçaose keuken. 10 Schepengalerij. 11 Curaçaose ,,Zaal”. 12 Meubelzaal. (Met de volgende figuur getekend met gebruikmaking van schetstekeningen van J. H. WERNER, dd Juni 1948, onder wiens leiding de restauratie van het museumgebouw werd verricht.) 


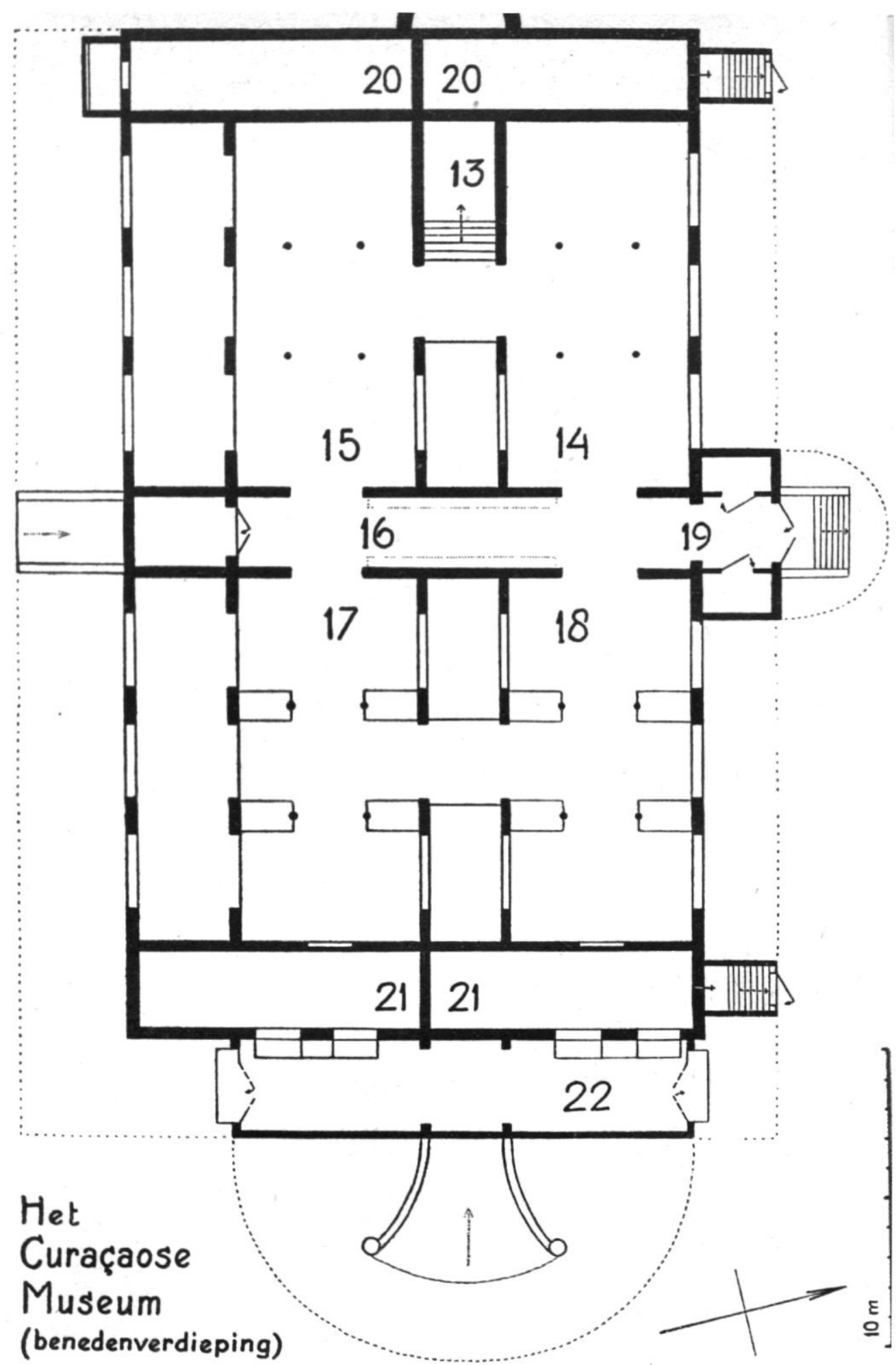

Fig. 3. Plattegrond van de benedenverdieping van het Curaçaose Museum: 13 Trap vi de bovenverdieping naar beneden. $14 \mathrm{Zaal}$ met oude verzamelingen, een folkloristisch kara ter dragend. $15 \mathrm{Zaal}$, in hoofdzaak gewijd aan de Indiaanse cultuur. 16 Gang met twee lan vitrinekasten, kaarin de kern van de geologische verzameling is ondergebracht. $17 \mathrm{Zaal} \mathrm{m}$ vier grote vitrines, in hoofdzaak aan de dieren en planten van het land gewijd. $18 \mathrm{Zaal} \mathrm{m}$ vier grote vitrines, aan de zee gewijd. 19 Benedenuit- en ingang. 20 Regenbakken. 21 Les regenbakken, als bergplaats in gebruik. 22 Werkplaats. 
De benedenverdieping (fig. 3), die grotendeels gereserveerd is voor natuurhistorisch en geologisch materiaal, heeft vier zalen van ongeveer 12 meter lang, 6 meter breed en $2 \frac{1}{2}$ meter hoog, die met elkaar door korte en brede doorlopen in verbinding staan, en met hun vloer 80 centimeter onder het maaiveld zijn gelegen. Oorspronkelijk was deze benedenverdieping slechts een lage, open bergruimte onder de vloer van een bovenverdieping, welke alléén voor woonruimte was bestemd. Het is stellig een goede gedachte geweest om deze bergruimte te veranderen in een , ,kelder”, welke een functie als tentoonstellingsruimte kon worden gegeven; zonder deze zou de ruimte in het gebouw volmaakt ontoereikend zijn geweest.

Elke benedenzaal ontvangt zijn daglicht slechts door drie boogvensters, die door stevig traliegaas zijn afgesloten. Hoe prettig dit ontbreken van ruiten ook voor de bezoekers is, toch heeft het in dit geval ook duidelijk zijn nadelen, als er veel stof of zelfs regen naar binnen wordt geblazen en door de onmogelijkheid om de vochtigheidsgraad in de tentoonstellingsruimten beneden die van de buitenlucht te laten dalen. Dit maakt een aantal bijzondere voorzieningen nodig om het tentoongestelde materiaal voor bederf te vrijwaren.

In de op het Noordoosten en het Zuidoosten gelegen zalen elk zijn vier grote, glazen vitrines gebouwd, van ongeveer $13 / 4$ meter breed, 1 meter diep en 2 meter hoog (fig. 4). Zij zijn thans grotendeels ingericht met nieuw-verzameld materiaal, aangevuld met geschenken van de musea in Amsterdam en Leiden en van het zoölogisch laboratorium in Utrecht. Indien er nog zes tafelvitrines, met bergruimte onderin, worden bijgeplaatst, en van de muurvlakken een goed gebruik is gemaakt, dan zullen deze twee lokalen aan hun bestemming reeds op waardige wijze kunnen beantwoorden.

Een tentoonstelling moet niet alleen maar een uitstalling zijn van bezienswaardige voorwerpen; zij behoort het publiek tevens een belangwekkende gedachtengang of een interessant vraagstuk voor te leggen, door de stukken in een bepaald verband en met een duidelijke uitleg te demonstreren. Verlichte aquaria en aquaterraria zullen voor de kleur en de beweging zorgen, die thans door vele natuurliefhebbers zo node wordt gemist. De drie tussenruimten zijn voor diorama's bestemd.

De kern van de geologische verzameling heeft in de dwarsgang reeds een uitstekende plaats gevonden. De op het Noordwesten gelegen zaal zal wellicht met voordeel een folkloristisch karakter kunnen blijven behouden, terwijl de op het Zuidwesten gelegen ruimte bijna geheel gewijd zou kunnen blijven aan de resten van oude cultuur. Indiaans aardewerk, stenen werktuigen, schelphopen, rotstekeningen en skeletten zijn op de Benedenwinden in voldoende mate gevonden om materiaal te kunnen leveren voor een boeiend en instructief geheel, dat betrekkelijk weinig zofg voor onderhoud nodig heeft.

Het museumgebouw is gelegen op een goed omrasterd terrein van bijna driekwart hectare: een verwaarloosd stuk kalksteenterras met nog wat tamarindebomen uit de oude tijd. Een museumtuin is hier in wording.

In het algemeen behoort men, bij de aanleg van een museumtuin, 
er op bedacht te zijn dat deze de algemene aandacht niet te veel van het gebouw afleidt, maar door zijn sfeer de geest van de bezoeker ontspant en zo meer ontvankelijk maakt voor de indrukken die hem binnen wachten. Aan de andere kant moet de tuin echter wel degelijk ook aan zekere eisen van plantenliefhebbers en botanici voldoen. Aan de oplossing van dit, bij Curaçaose omstandigheden niet zo eenvoudige vraagstuk - moeilijk ook omdat in de tuin dingen moeten worden tentoongesteld die in het gebouw geen plaats kunnen vinden - wordt, onder leiding van frater ARNOLDO, gestadig doorgewerkt.

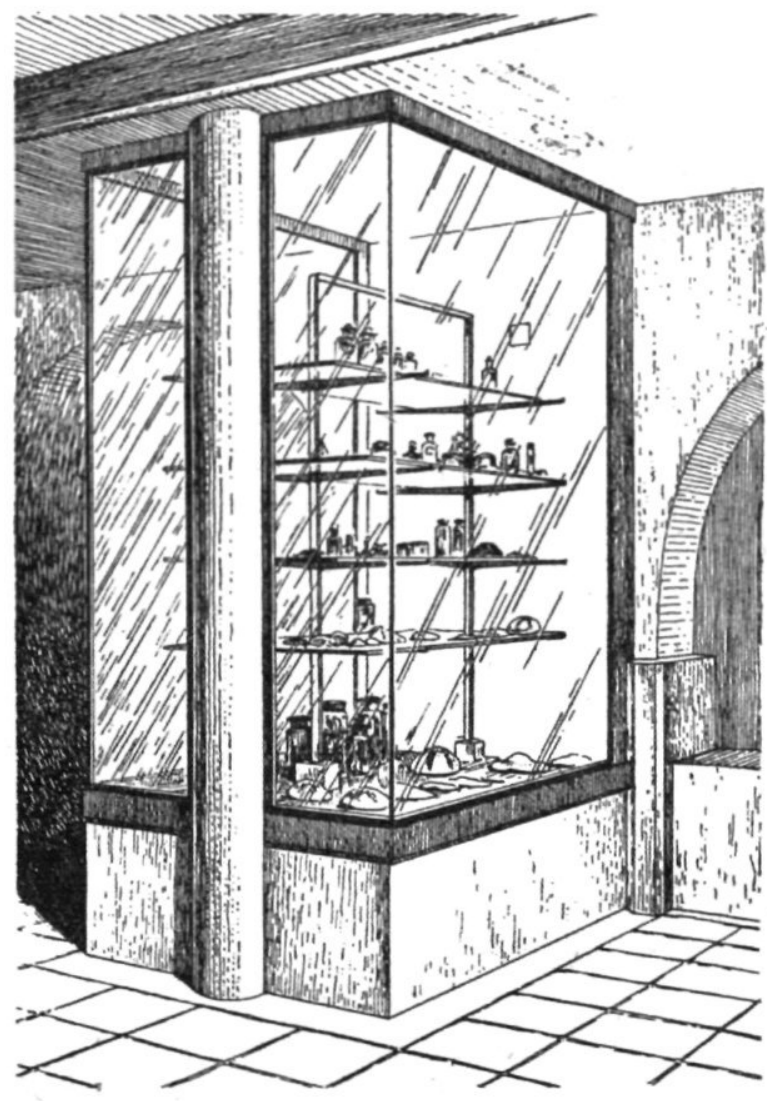

Fig. 4. De echinodermen-vitrine, in de op het Noordoosten gelegen zaal, waarin materiaal van zeeëgels, zeesterren en zeekomkommers wordt tentoongesteld. (Naar een foto getekend door J. PRIJS).

Aan de wens tot het houden van enkele levende dieren werd tegemoet gekomen door het bouwen van een grote vogelkooi en de aanleg van een leguanenkuil.

Maar er zijn nog méér en belangrijker uitbreidingen nodig. Onmisbaar is bijvoorbeeld een kleine, goed te ventileren ruimte, waarin allerlei dingen die onderhevig zijn aan schimmelaantasting en insectenvraat, 
op geregelde tijden kunnen worden ontsmet. Deze zou wellicht kunnen worden geprojecteerd in een bescheiden gebouwencomplex - waaraan ook al om andere redenen behoefte bestaat - dat misschien het beste rechts van de hoofdingang tot het terrein zou kunnen verrijzen, samen met een prepareerkamer en een overdekte ruimte waar proefbakken kunnen worden neergezet, voorwerpen kunnen worden gedroogd en van allerlei opgeslagen.

Het belang van een natuurwetenschappelijk museum voor de Curaçaose samenleving is moeilijk met slechts enkele woorden aan te duiden. Vóórop stelle men zijn betekenis voor de bevolking en wel in het bijzonder door het bijbrengen van meer belangstelling voor de natuur. Maar dan moet er ook iets van het museum uitgaan, waardoor het die personen tot zich trekt voor wie het een geestelijke vervulling zou kunnen zijn.

Het Museum heeft de medewerking van velen nodig; vooral nu het zich nog bevindt in een beginstadium, waarbij voortdurende, deskundige leiding ontbreekt. Het is natuurlijk van groot belang, dat het kan rekenen op de hulp van de „Natuurwetenschappelijke Werkgroep", die haar gewone bijeenkomsten in het Museum belegt en haar zorgen zoveel mogelijk uitstrekt naar de benedenverdieping en de tuin. Maar dit blijft slechts een zéér onvoldoende, noodgedwongen voorziening, zolang er niemand is aan wie de verzorging van de natuurwetenschappelijke verzamelingen kan worden opgedragen.

Wil het Museum zijn veelzijdige taak naar behoren kunnen vervullen, dan zal het voortdurend de beschikking moeten hebben over een persoon, die leiding kan geven bij het verzamelen, prepareren en uitstallen van het materiaal, en die er voor zorgt, dat de verzamelingen een opvoedende, wetenschappelijke en aesthetische betekenis verkrijgen en ook behouden. En dàn ook pas zal het Museum met ere kunnen worden ingeschakeld in het toeristenbedrijf, dat voor Curaçao zo'n belangrijke bron van inkomsten betekent.

Leerzaam in deze is de grote vooruitgang van het Natural History Museum in Kingston, tijdens de tien jaren dat C. BERnard Lewis als curator aan het „Institute of Jamaica" is verbonden. Kon vroeger de verzameling vergeleken worden met een ouderwets natuurhistorisch kabinet, thans is deze uitgegroeid tot een modern museum, dat naast zijn functies als wetenschappelijk archief ook een opvoedende taak vervult. LEwIS maakte het museum bovendien tot het centrum van activiteit van de ,Natural History Society of Jamaica” en publiceert opstellen van leden, die ook als schoollectuur waardering vinden.

Een museum behoeft geen onderwijscollectie te zijn om een 
rol te kunnen spelen bij het onderwijs. Is de inrichting eenmaal zover, dat zij aan bepaalde eisen van overzichtelijkheid, etikettering en demonstratie voldoet, dan zullen stellig steeds meer leerkrachten het prettig vinden een lesuur in het Museum te geven. Er moeten ook rondleidingen worden georganiseerd, vooral voor de jongeren, en wel zó, dat elke schoolklas, te beginnen met de derde klasse, bv. ééns per twee jaar de kans krijgt, om onder deskundige leiding het Museum en zijn tuin te bezichtigen.

Men zou zich kunnen afvragen, hoe het komt, dat een instelling, welke toch voor de Gemeenschap, en in het bijzonder voor het onderwijs, zo ontzaggelijk veel zou kunnen betekenen, op Curaçao tot nu toe slechts zó'n wankele financiële basis heeft, dat voor elke gulden aan inkomsten nog steeds moet worden gevochten. Veel méér mensen moeten ervan worden doordrongen hoe een groot voorrecht het is een museum als dit te bezitten, opdat in grotere mate dan thans de handen zullen kunnen worden ineengeslagen om „Het Curaçaosche Museum” te maken tot een bezit van het gehele volk!

Een biologisch station?

De „Studiekring” en de „Werkgroep” hebben een ideaal: De vestiging van een biologisch station! Een biologisch station dat het systeem van uitwisseling van onderzoekers onder een coördinerende leiding als grondslag van werken heeft. Een instituut, dat gelegenheid biedt tot het doen van natuurwetenschappelijke onderzoekingen over de Nederlandse Antillen, en waar bij voorkeur onderwerpen zullen worden aangepakt die voor deze eilanden van betekenis zijn.

Een biologisch station op de Nederlandse Antillen zal in de eerste plaats een marine-biologisch karakter moeten dragen, want - hoe kenmerkend en van een hoe grote wetenschappelijke betekenis de dieren- en plantenwereld van het land en van het zoete en brakke water ook zijn, alles wordt overheerst door de overweldigende rijkdom van de Caraïbische Zee, waardoor een ieder wordt geboeid en waaraan zulk een praktische betekenis is verbonden.

De omvang en de bezetting van dit station hangt natuurlijk af van de eisen welke aan deze inrichting worden gesteld, waarbij echter aan enkele minimumvoorwaarden moet worden, voldaan, wil de opzet van het geheel aan zijn doel beantwoorden. 
Wat de bezetting betreft, hiervan lijkt het minimum te liggen bij: één directeur, die liefst visserij-biologisch geschoold moet zijn, één academisch gevormde assistent, een amanuensis en twee man lager personeel.

De figuur van de directeur is uitermate belangrijk voor de rol welke het biologisch station in de Antilliaanse samenleving zal spelen. Deze persoon moet de eilanden behoorlijk leren kennen en belangstelling hebben voor land en volk; hij moet het werk, dat op of ten behoeve van het biologisch station wordt verricht, coördineren en het een richting geven welke het meest gewenst is. Het onderzoekingswerk zal in hoofdzaak moeten worden gedaan door de assistent en de onderzoekers die van buiten komen en gastvrijheid op het station genieten.

Indien men op de Nederlandse Antillen in beginsel tot de oprichting van een dergelijk instituut mocht besluiten, dan zal het nodig zijn, dat een organisatie zoals wij reeds bezitten in de „Natuurwetenschappelijke Studiekring voor Suriname en Curaçao" - in overleg met universiteiten, musea en verenigingen - de uitzending van drie of vier personen per jaar mogelijk maakt. Samenwerking met de „Research Council” van de „Caribbean Commission" en met Amerikaanse universiteiten en musea is dan natuurlijk gewenst.

In dit opzicht is het van belang, dat het ,American Museum of Natural History" reeds een aantrekkelijk laboratorium op het kleine eilandje Bimini, in de Bahamas, exploiteert, dat de ,University of Miami” het in Caraïbische kringen al zeer bekende „,Marine Laboratory" onder haar hoede heeft, en dat de ",New York Zoological Society" zeer onlangs een station in het heuvelland van Trinidad heeft geopend.

"The Lerner Marine Laboratory"' op Bimini is een goed voorbeeld voor een biologisch station op onze Antillen. Daarom moge er hier iets meer over worden medegedeeld naar gegevens welke door WAGENAAR HumMELINCK tijdens een kort bezoek - dat met steun van het ,,Welvaartsplanbureau Nederlandse Antillen" en de „Curaçaose Toeristen Commissie" aan Bimini kon worden gebracht — werden verzameld. Al zal het schone toekomstbeeld, dat ons daarbij voor de Nederlandse Antillen voor ogen zweeft, ook in belangrijke punten moeten afwijken van het in Bimini aanschouwde.

Bimini is de naam van de meest Westelijk gelegen eilandengroep van het enorme eilandenrijk der Bahamas. Het ligt een goede honderd kilometer van Miami, vanwaar het met gecharterde vliegtuigen of per mailboot is te bereiken. Met het toeristencentrum Nassau is er verbinding per vliegtuig en mailboot, eens in de veertien dagen.

North Bimini, waar het laboratorium is gelegen, bestaat uit een brede wal van zand en zandsteen van nauwelijks zes meter hoogte, 


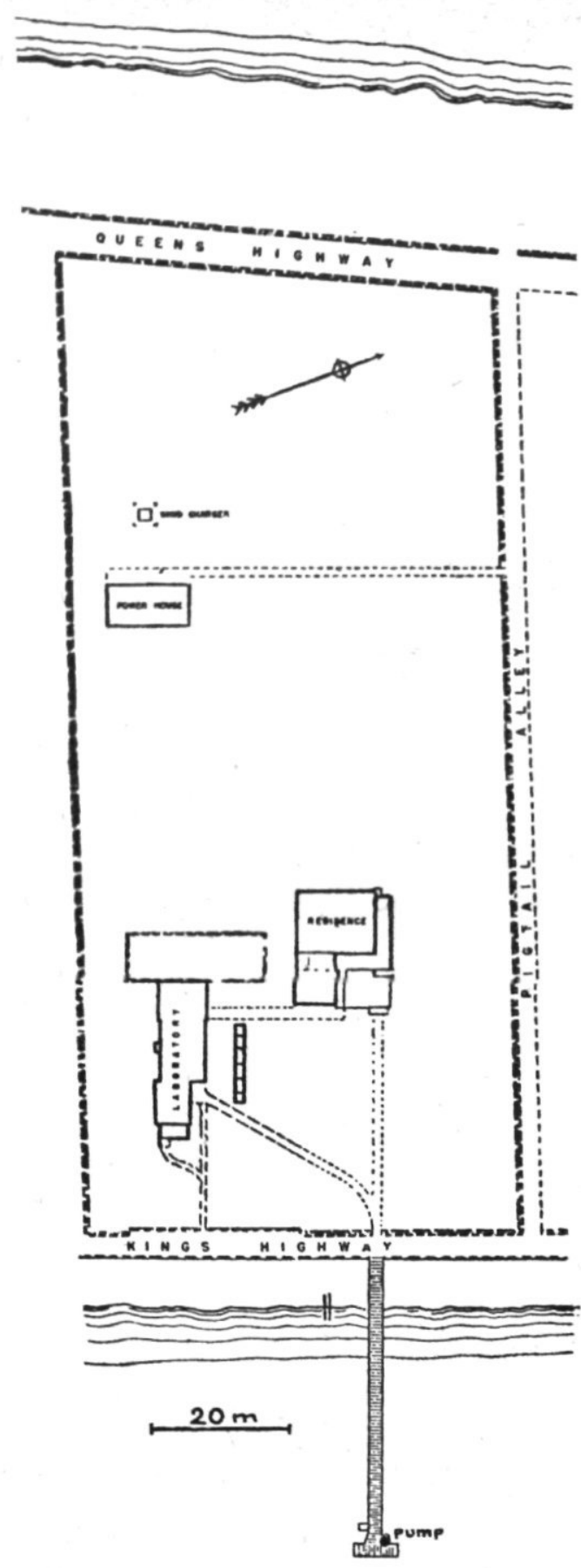

Fig. 5. Plattegrond van het terrein van The Lerner Marine Laboratory, dwars over het eilandje North Bimini heen: Het laboratoriumgebouw met daarnaast zes zeewaterbakken, het logeergebouw en het krachtstation met de windgenerator. Aan de Oostzijde is de steiger ver in de ondiepe lagune uitgebouwd.

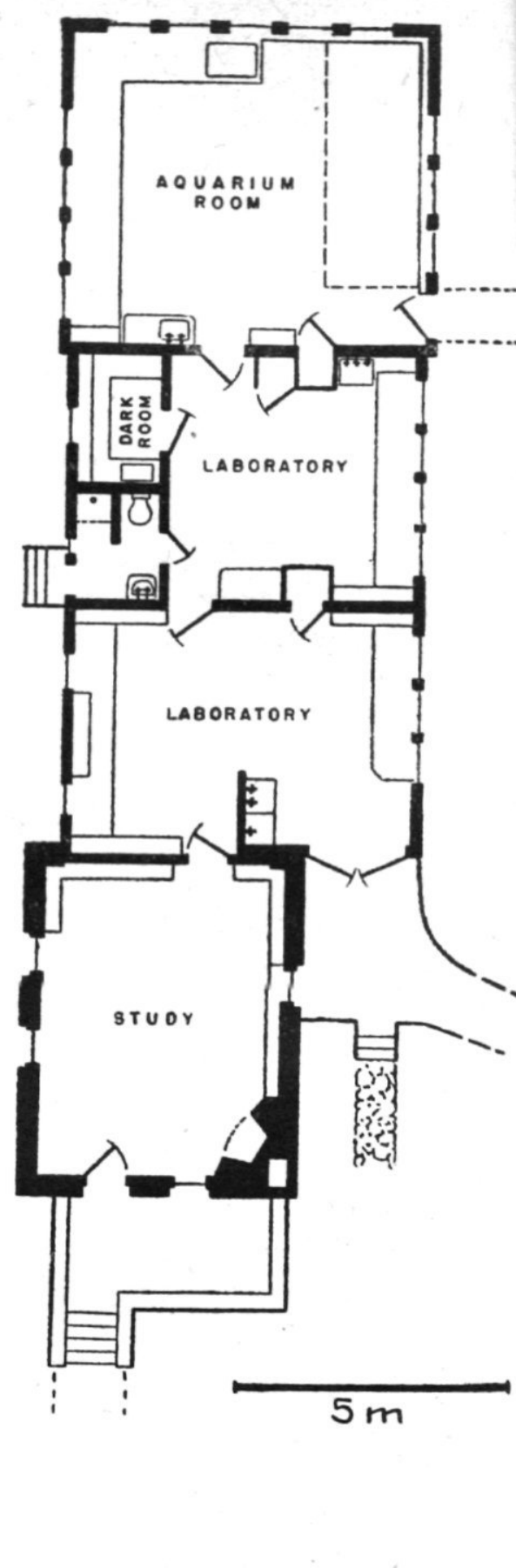

Fig. 6. Plattegrond van het laboratorium gebouw op Bimini: Een aquariumzaal, twe laboratoriumruimten met donkere kame en een bibliotheek met terrasje. (Met d vorige figuur naar tekeningen uit ees brochure over het laboratorium). 
welke naar het Oosten toe een ondiepe lagune met een mangrovevegetatie omsluit en aan de Westzijde door het water van de Golfstroom wordt bespoeld (fig. 10).

Nadat het besluit, om op North Bimini een biologisch station te vestigen, door Michael Lerner (voorspoedig Amerikaans zakenman, jager op grof wild en hengelaar van wereldnaam) en ChARLES M. BREDER JR (hoofd van ,,The Department of Fishes and Aquatic Biology" van het ,American Museum of Natural History") tijdens een gezamenlijke tocht was genomen, werd een strook grond gekocht van $21 / 3$ acre, dwars over het smalle eiland heen (fig. 5). Op 29 Maart 1948 werd het laboratorium geopend en daarna aan het "American Museum" overgedragen.

Directeur is Charles M. Breder JR, die zoveel als zijn bezigheden in New York dit toelaten, in Bimini te vinden is. Er bestaat geen vaste wetenschappelijke staf. Het laboratorium wordt toevertrouwd aan de zorgen van de gasten en aan drie man personeel.

$\mathrm{Na}$ drie maanden had men al gastvrijheid geboden aan 23 onderzoekers, die tezamen 569 dagen onderzoek hadden verricht; de twaalf volgende maanden kwamen er 25 , met 1433 werkdagen.

Het laboratorium (fig. 6) biedt ruimte aan omstreeks tien onderzoekers. $\mathrm{Er}$ is - om aan de achterzijde van het gebouw te beginnen een aquariumzaal met bovenlicht (fig. 12); een microscopeerzaal met donkere kamer, en een sectielocaal. Overal zijn natuurlijk de nodige stopcontacten, kranen voor zeewater en warm en koud regenwater. Aan de voorzijde bevindt zich de bibliotheek: een uit natuursteen opgetrokken gebouwtje.

De voorkant van het laboratorium ligt op het Oosten, waar een steiger, van bijna vijftig meter lengte in de ondiepe lagune is uitgebouwd (fig. 5). Hier is een pompje opgesteld, dat het laboratorium van zeewater voorziet.

Er zijn vier boten. De grootste heeft een $60 \mathrm{pk}$ motor. In grootte volgen hierop: een ter plaatse gebouwde boot voor ondiep water, een boot met bodem-venster en een klein roeibootje, die zijn uitgerust met achtereenvolgens een 25,10 en $5 \mathrm{pk}$ buitenboord motor. Naast de steiger is een eenvoudige constructie gemaakt om de boten ook buiten het water te kunnen repareren.

Dicht bij het laboratoriumgebouw vinden wij zes open bakken van beton - elk omstreeks 2 meter lang, $1 \mathrm{~m}$ breed en $1 / 2$ meter diep waarin verschillende zeedieren worden gehouden.

De „,Residence”, waar de onderzoekers een uiterst gastvrij en comfortabel onderdak vinden, ligt op slechts enkele tientallen meters van de werkruimten verwijderd. Er zijn tien bedden en de huishouding wordt door een niet-inwonende huishoudster met éen gedienstige gedreven.

Meer naar achteren staat het krachtstation, met de benzinegenerator, die, tezamen met een windgenerator, de nodige electrische stroom levert.

De grootste bezienswaardigheid van Bimini zijn ongetwijfeld de Fish Pens (fig. 7) - enkele honderden meters bezuiden het laboratorium gelegen - die wel als een persoonlijke liefhebberij van de stichter 
van het laboratorium mogen worden beschouwd. $\mathrm{Zij}$ bestaan uit vijf rechthoekige bakken of afrasteringen, met een totaal oppervlak van bijna $800 \mathrm{~m}^{2} ; 1 \frac{1}{2}$ tot $21 / 2 \mathrm{~m}$ diep. De kleinste is een bak met betonnen wanden; de grotere zijn afrasteringen, geheel uit palen en gaas opgetrokken. Verder zijn er natuurlijk nog kleinere ruimten voor het bewaren van voedselvissen en een platform waar iedere dag honderden carcó's van hun schelpen worden ontdaan.

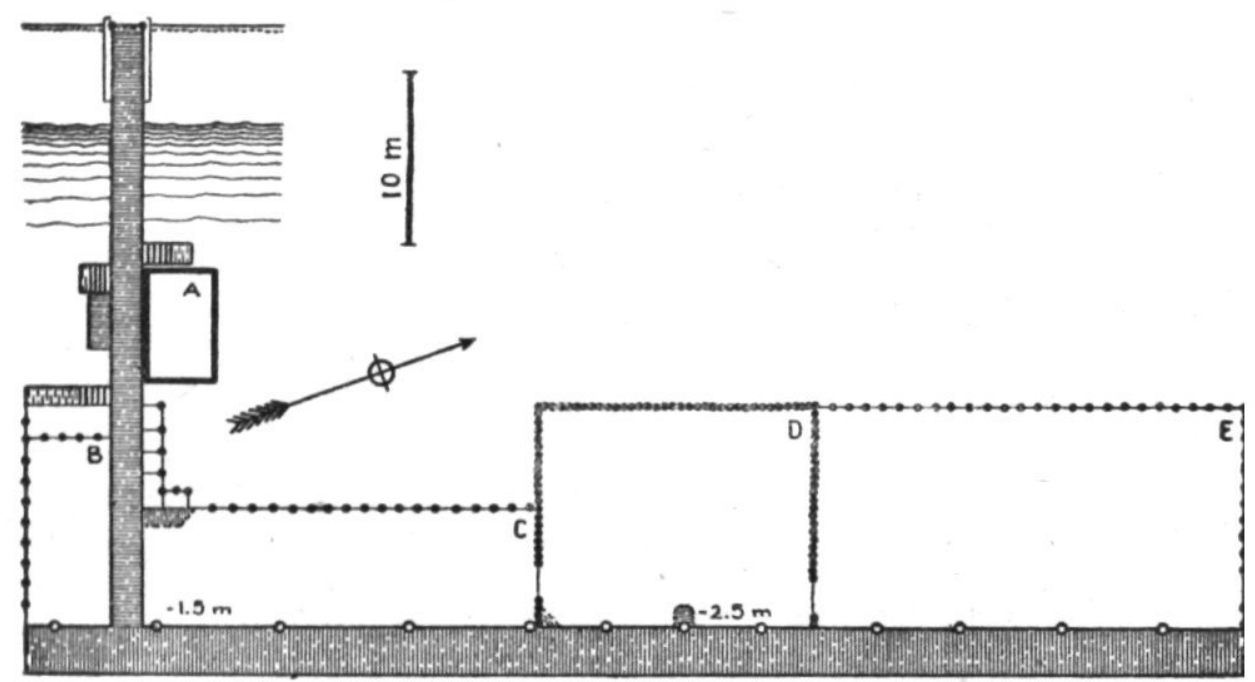

Fig. 7. Plattegrond van de Fish Pens op Bimini: Een grote L-vormige steiger met een betonnen bak (A), één afgepaald gedeelte (D) en drie ruimten welke met gaas zijn afgerasterd (B, C, E). De steiger welke evenwijdig aan de kust loopt, wordt 's avonds door twaalf lampen verlicht. (Grove schets; afmetingen geschat).

De betonnen bak was kennelijk voor ,,rare" vissen - zoals koffer-, trompet- en egelvissen - bestemd. In de, in grootte hierop volgende ruimte zwommen honderden blauwe papegaaivissen. Dan kwam er een tank met vele grote barracuda's, haaien, remora's en schildpadden, en vervolgens een die bewoond was door twee bruinvissen, twee enorme jodenvissen en een ontzaglijke rog. De grootste afrastering was niet in gebruik. Twee maal per dag werden de dieren gevoederd; iedere belangstellende kon hiervan getuige zijn (fig. 11). Tot één razend blauw kluwen werden dan de papegaaivissen, als een ontploffing was het openen van de ontzagwekkende muilen van de jodenvissen, en keurig sprongen de bruinvissen één voor één uit het water om de vis te grijpen die de oppasser ze aanrijkte.

Als plaats van vestiging van een marien-biologisch station op de Nederlandse Antillen lijkt de kust bij Kralendijk, op Bonaire, zeer aantrekkelijk. Allerlei levensgemeenschappen van een opvallende zuiverheid en verscheidenheid kan men op dit 
eiland bestuderen. Men leeft er eenvoudig, temidden van een bevolking van grotendeels vissers en landbouwers, en heeft geen speciaal middel van vervoer nodig om het station, dat op gouvernementsgrond kan worden gebouwd, te bereiken. De zee is er kalm, het water is er helder en niet verontreinigd door olie of afval van de olie-industrie.

Waar de ,koralendijk" - die plaatselijk tot een betonachtige massa is aaneengekit - door de branding is aangetast, is zij, in de getijdezône, met allerlei planten en dieren bedekt en met etsende of borende organismen doortrokken. Soms zijn er lange drempels uitgeprepareerd, die bij laag water droog vallen (fig. 13-14). Strandpoeltjes vormen dan een prachtig verzamelterrein.

Stappen we over de overhangende buitenste drempel, dan staan we op een ondiep terras, waar - tussen allerlei koralen en steenbrokken heftige zandstormen woeden, en waar de gevreesde zwarte zeeappels in massa's op strategische punten liggen opgesteld (fig. 15). In deze zône imponeert ons direct het elandsgewei-koraal: enorme waaiers, zwaar en stevig, maar toch ook weer als kantwerk zo fijn (fig. 16). Iets verder komen we aan het dichte struikgewas van het sierlijke hertshoorn-koraal (fig. 17), dat langs de gehele kust in grote hoeveelheden voorkomt en waaruit ook de puinwallen, die men langs de kust vindt opgeworpen, grotendeels bestaan. Het ondiepe, zandige terrein wordt dan geleidelijk lager, tot het op ongeveer vijf meter diepte, vrij plotseling, tussen de wuivende zeewaaiers in de donkerblauwe diepte wegduikt.

Voor het wetenschappelijke werk zou een aantal, geheel onder contrôle staande kleinere aquaria en proefbakken in het algemeen voldoende kunnen worden geacht. Op Curaçao bleek men echter niet zo zeer belang te stellen in de mogelijkheden van onderzoek, als wel in een $\mathrm{sh}$ o w-a q u a ri u m, dat niet alleen natuurliefhebbers tot zich trekt, maar dat ook de belangstelling van min of meer onverschillige en verwende toeristen vermag te wekken.

Een dergelijke wens lijkt op een van de Benedenwindse Eilanden wel te verwezenlijken; vooral indien de opzet eenvoudig wordt gehouden en het aquarium, méér dan elders het geval is, aan het natuurlijke milieu is aangepast. Er mag dus geen pompinrichting aan verbonden zijn, waardoor de exploitatiekosten sterk zouden worden verhoogd en de risico's toenemen. De waterbeweging van de zee zelve moet dus voor de verversing van het water in de bakken zorgdragen!

Het show-aquarium zou kunnen bestaan uit een aantal open bakken van verschillende vorm en afmetingen, welker bewoners niet alleen van boven af kunnen worden bekeken, maar ook 
bestudeerd uit een donkere gang beneden de waterspiegel. De aanleg zou duur zijn, maar het onderhoud waarschijnlijk betrekkelijk goedkoop, terwijl de bakken een verzameling van dieren onder omstandigheden als nergens anders ter wereld zouden demonstreren.

Gezien de hoge kosten welke de bouw met zich zou medebrengen, lijkt het verstandig een dergelijk aquarium vooreerst nog te beschouwen als een commercieel object, waarvan de exploitatie een belangrijk deel van de onkosten moet kunnen dekken. Dit houdt in, dat de inrichting hiervan vooralsnog alléén op Curaçao mogelijk is. Het biologisch station, dat, niettegenstaande zijn verschillende doelstelling, het aangewezen lichaam zou zijn om het show-aquarium te beheren, zou dan eveneens op dit eiland gelegen moeten zijn. Hierdoor zou dan meteen worden tegemoet gekomen aan hèt grote bezwaar dat men tegen een vestiging op Bonaire kan aanvoeren: dat een bezoek voor een groot aantal op Curaçao vertoevende personen al direct onmogelijk zou zijn.

Aldus werd op Curaçao naar een plaats voor een biologisch station plus aquarium uitgekeken.

Toen VAN DER HoRST in 1920 op Curaçao verzamelde, dacht hij dat het oude Quarantaine-Gebouw bij de Caracas-Baai uitstekend geschikt zou zijn voor een permanent zoölogisch station; in een prachtige omgeving met een grote verscheidenheid van kustvormen in de onmiddellijke nabijheid.

Caracas-Baai is nu een belangrijk bunkerstation voor stookolie geworden, maar het vlak hierbij gelegen Spaanse Water is nog vrijwel ongerept. Indien VAN DER HORST nu nòg eens Curaçao zou bezoeken, dan zou ook hij stellig het zandstrandje aan de ingang van het Spaanse Water, met de rand van het daarachter gelegen lagen kalksteenterras, als de beste plaats voor een marien-biologisch station op Curaçao beschouwen (fig. 8, 19-23).

De ingang van het Spaanse Water is een kanaal van nauwelijks honderd meter breed en een kilometer lang, dat toegang geeft tot een grillig binnenwater van ongeveer twee bij drie kilometer. Het is een, na de IJstijd volgelopen erosiedal tussen kalksteenterrassen die landinwaarts langzaam oprijzen en dan steil afbreken, met daarachter een heuvelig binnenland, dat met zijn veel gemakkelijker verweerbare diabaasbodem lager ligt dan de kalksteenterrassen langs de kust. De 


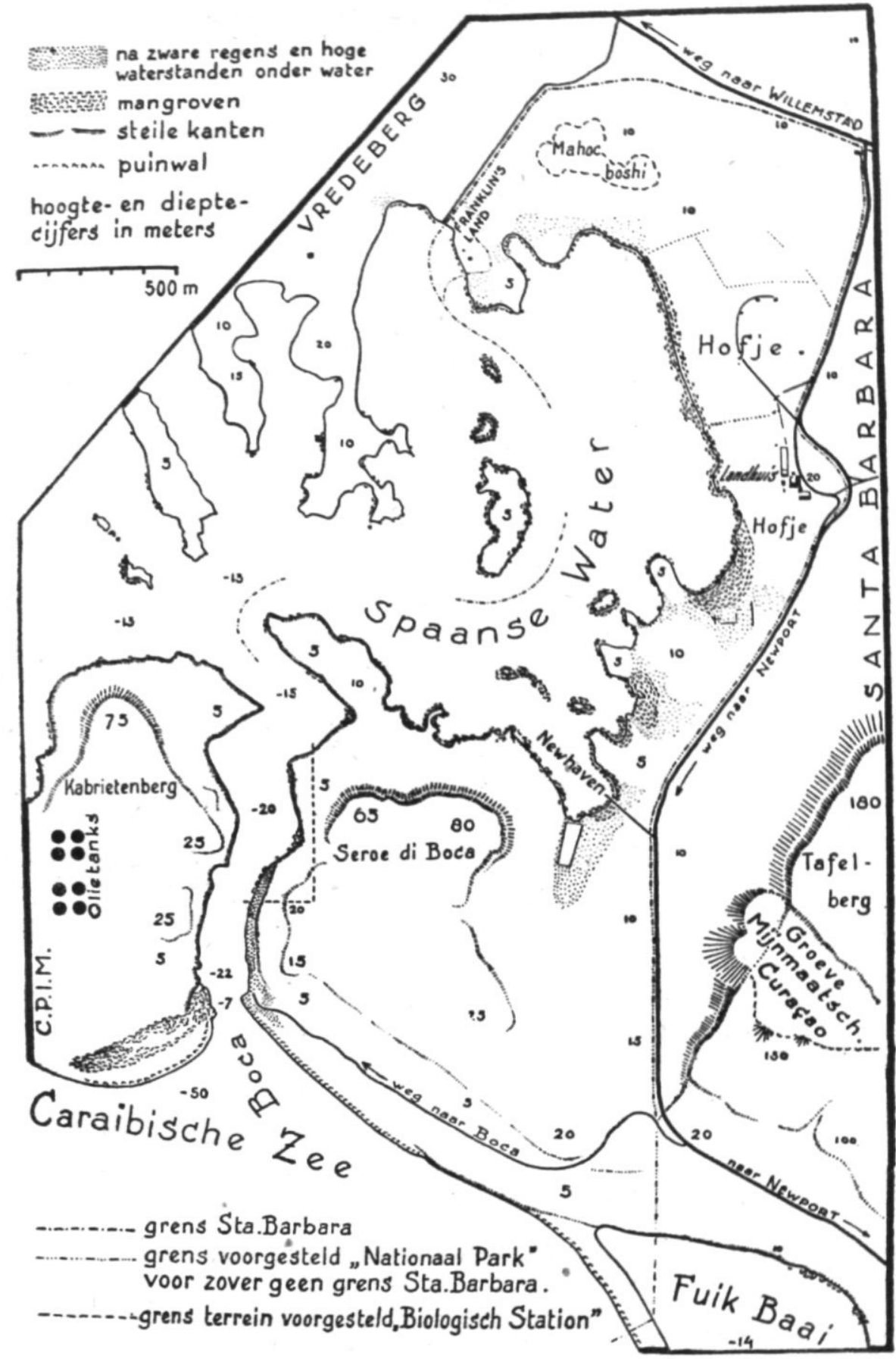

Fig. 8. Schetskaartje van het grootste gedeelte van het Spaanse Water, op Curaçao, met het aangrenzende deel van de plantage Santa Barbara.

(Getekend met gebruikmaking van luchtfoto's van de K.L.M.). 
vaargeul is bij de monding meer dan twintig meter diep, met een drempel van ongeveer zeven meter.

Waar op de Oostelijke oever nog enkele bomen zijn te vinden, ligt, vóór het lage kalksteenterras, een smalle zandstrook met aan de waterkant enkele mangroven; dan volgt een zwak hellend, ondiep deel van ruim twintig meter breed en vervolgens vrij snel een diepe geul.

Een nationa a 1 park?

Bij een nadere bestudering van de mogelijkheden van dit plan waarbij contact werd opgenomen met de „Mijnmaatschappij Curaçao”, eigenaresse van de plantage Santa Barbara, waartoe dit terrein behoort - kwam het denkbeeld naar voren van het stichten van een soort n a ti o na 1 park, dat (behoudens een kleine uitzondering: Franklin's land) àl het terrein zou omvatten bewesten de grote weg van Sta Barbara, naar het Zuiden recht doorgetrokken tot aan de Fuik-Baai (fig. 8); ongeveer 250 hectaren.

Op dit terrein liggen als bijzondere objecten nog: ten eerste het prachtige landhuis van Santa Barbara, helaas wat vervallen, maar thans nog bewoond en waarschijnlijk wel zonder tè grote offers te restaureren; ten tweede een groot, thans nog in exploitatie zijnd hofje, en verder een opstand van mahonie-bomen.

Hoewel de besprekingen nog geen enkel definitief resultaat hebben opgeleverd, is het te hopen, dat geheel dit prachtige terrein als nationaal park zal worden behouden. En dan natuurlijk liefst met een aantrekkelijk biologisch station aan een olievrij strand.

Een eenvoudige opzet voor een doeltreffend onderzoek.

Zij die De West kennen, zullen terecht tegenwerpen, dat het plan van een biologisch station op de Nederlandse Antillen wel wat groot van conceptie is, met name nu de eilanden zich bevinden in een periode van bestuursemancipatie en van ontwikkeling van een eigen cultuur.

Een van de eerste opgaven waarvoor het bestuur van de jonge „Werkgroep" zich dan ook zag geplaatst, was het bedenken van een vorm van onderzoek, welke bij de huidige omstandigheden kans op verwezelijking biedt en waarvan toch een groot nuttig effect kan worden verwacht.

De eerste stap was een verzoekschrift aan de Antilliaanse Volksvertegenwoordiging, waarin werd gevraagd om gedurende een aantal jaren een bedrag beschikbaar te stellen, teneinde gevorderde studenten of afgestudeerde biologen op de Nederlandse Antillen onderzoekingswerk te kunnen laten verrichten, waaraan behoefte is. Deze onderzoekingen zouden dan in Nederland moeten worden uitgewerkt. $\mathrm{Zij}$ die voor uitzending in aanmerking komen, zouden, naast hun uiteraard dikwijls specialistisch werk, ook een meer algemene taak hebben te vervullen, 


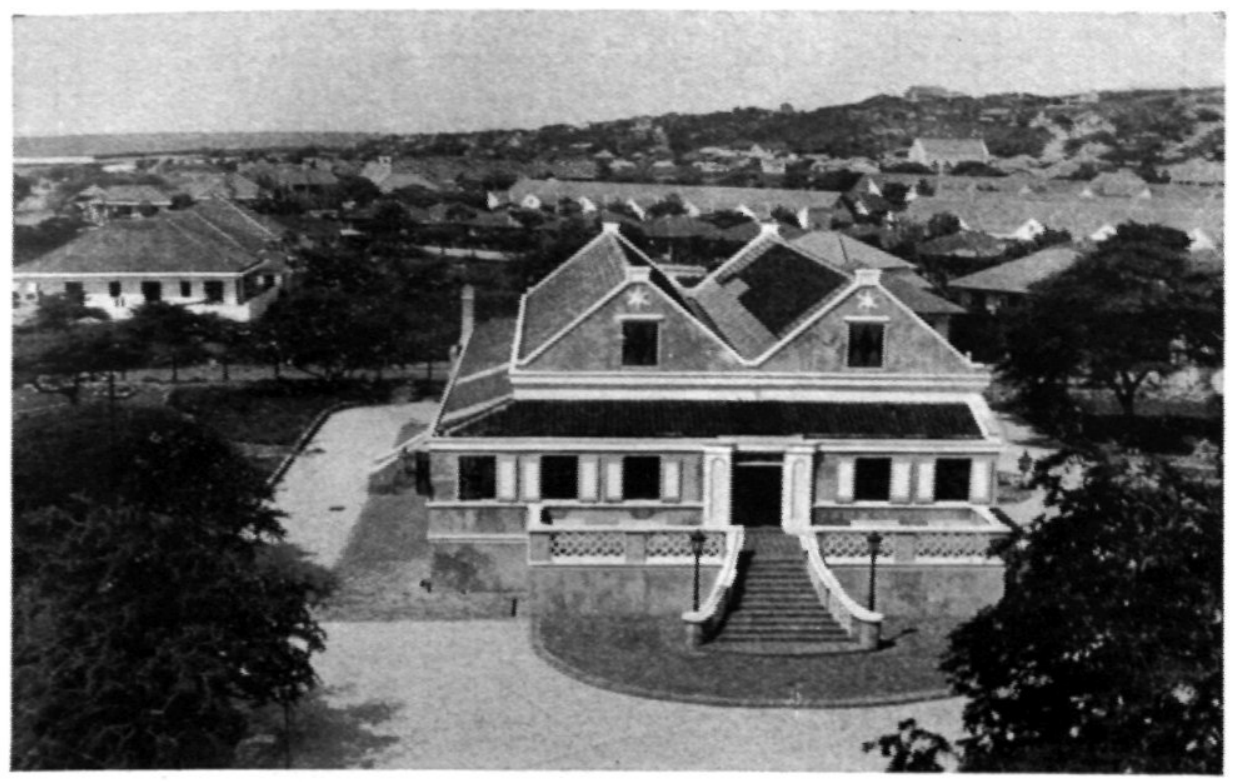

Fig. 9. Het Curaçaose Museum. Op de achtergrond de zee en Charo (Nov. 1948).

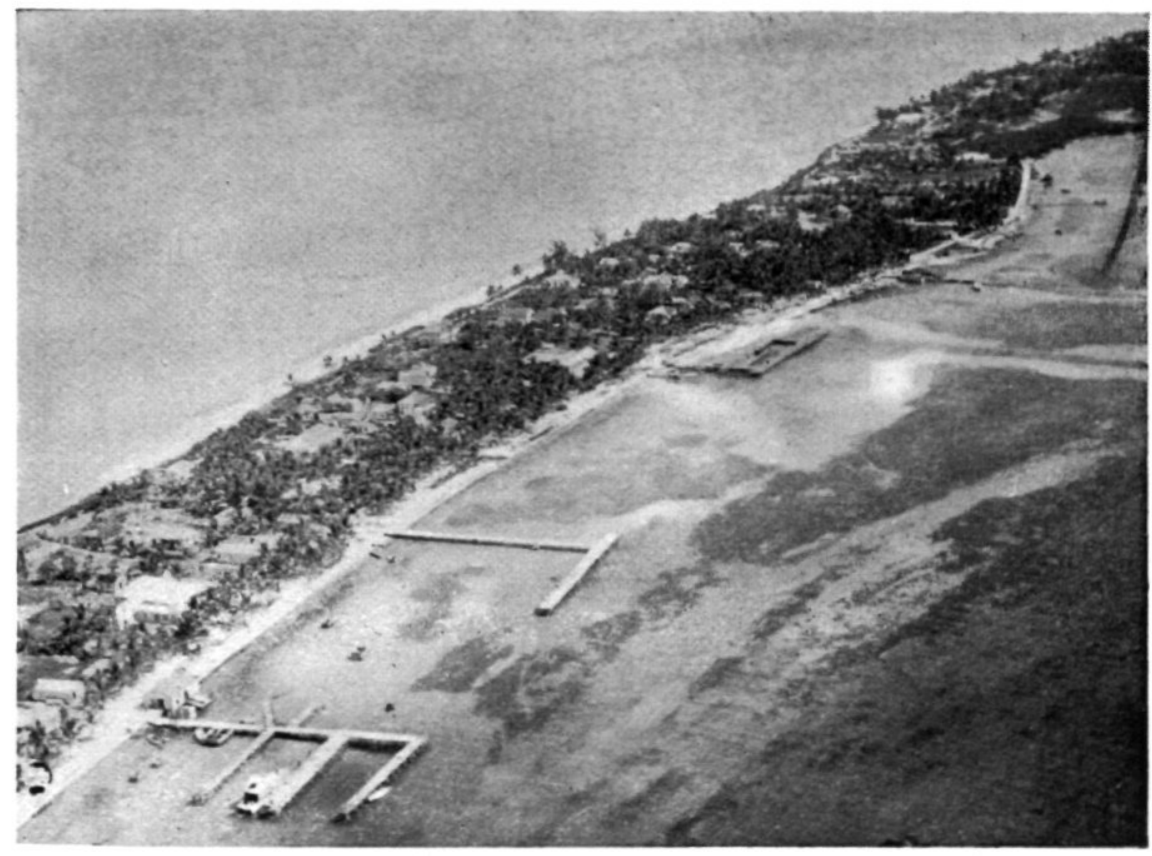

Fig. 10. Zuidelijk deel van het eiland North Bimini (Bahamas) in vogelvlucht. Een zandwal met veel cocospalmen, waartussen hotels en zomerhuizen. In de ondiepe lagune zijn steigers gebouwd: links onder de grote steiger van Alice Town, even boven het midden de Fish Pens en geheel rechts boven de steiger van het laboratorium. De donkere vlekken in het water zijn plaatsen waar de bodem met zeegras is begroeid (Aug. 1949). 


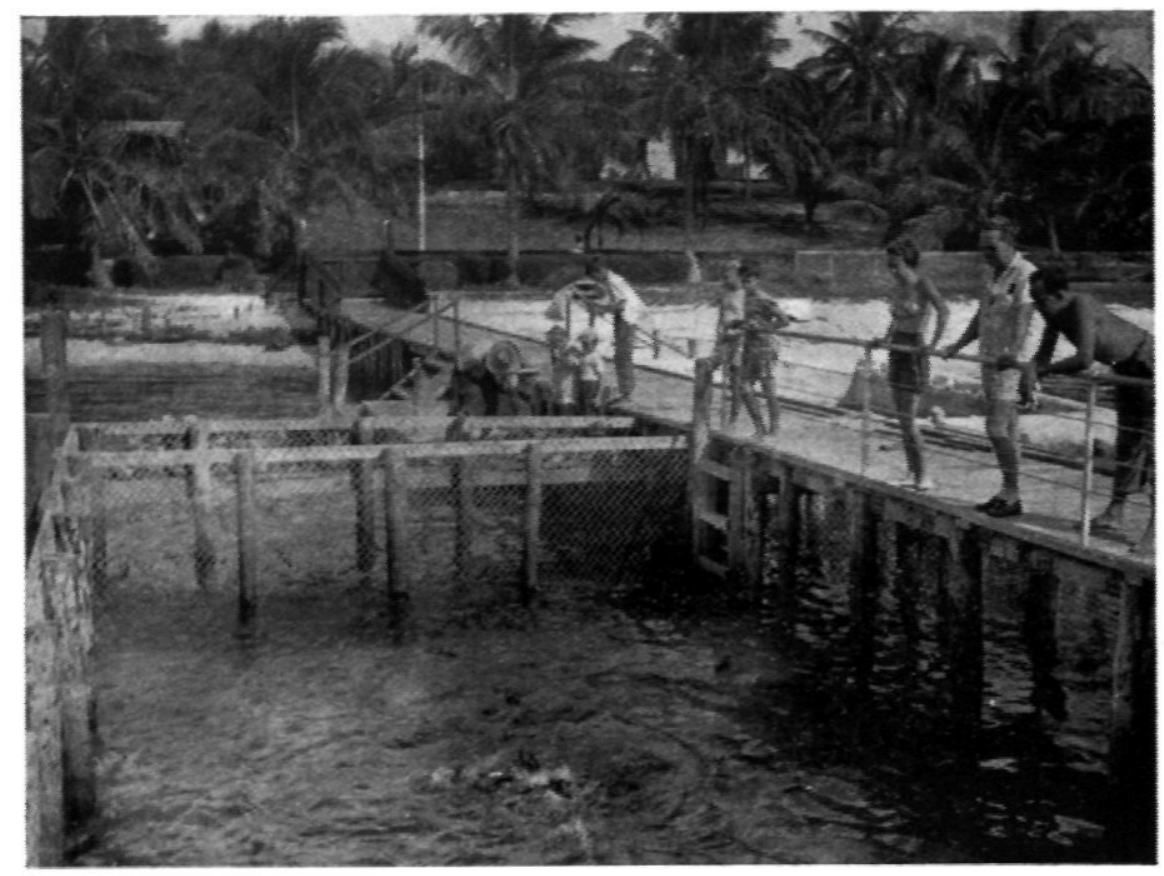

Fig. 11. Toeristen kijken naar het voederen van de blauwe papagaaivissen in de Fish Pens van Bimini (Aug. 1949).

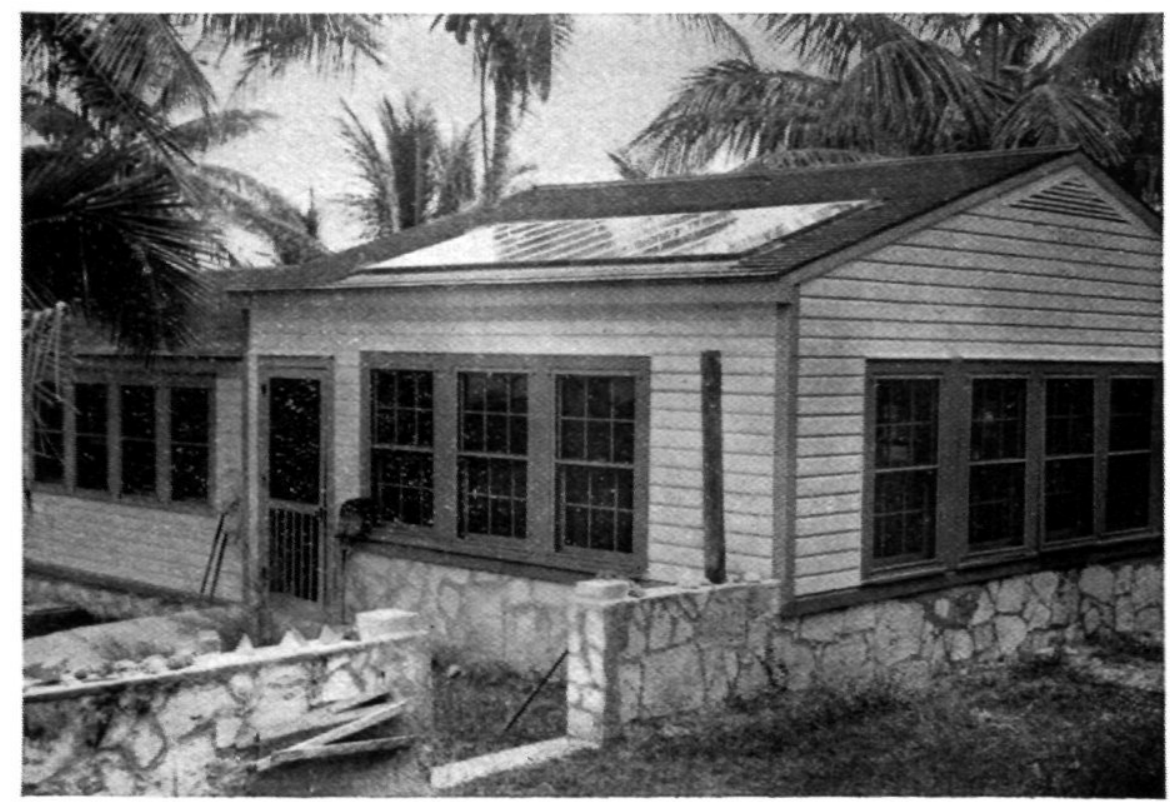

Fig. 12. De aquariumzaal van The Lerner Marine Laboratory op Bimini (Aug. 1949). 


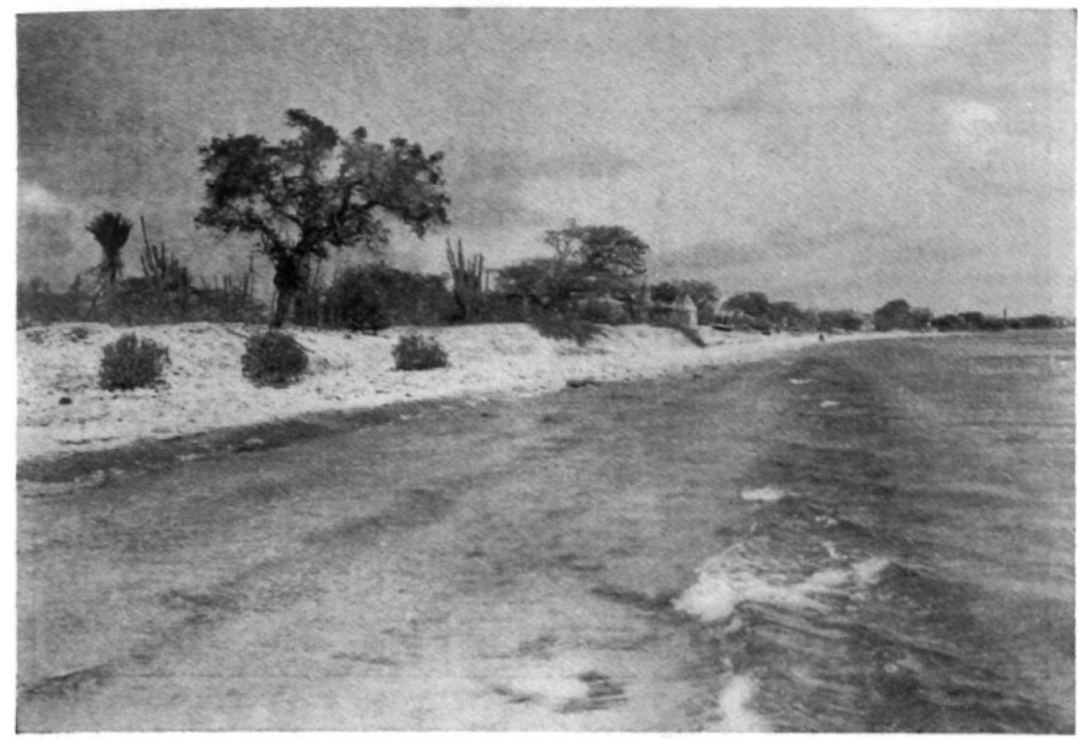

Fig. 13. De kust bij Paloe Lechi, op Bonaire, met Kralendijk geheel op de achtergrond. De basis van de witte wal van koraalpuin is tot een betonachtige massa aaneengekit en door de branding uitgeprepareerd tot lange drempeis, waarover de golven breken (Sept. 1948).

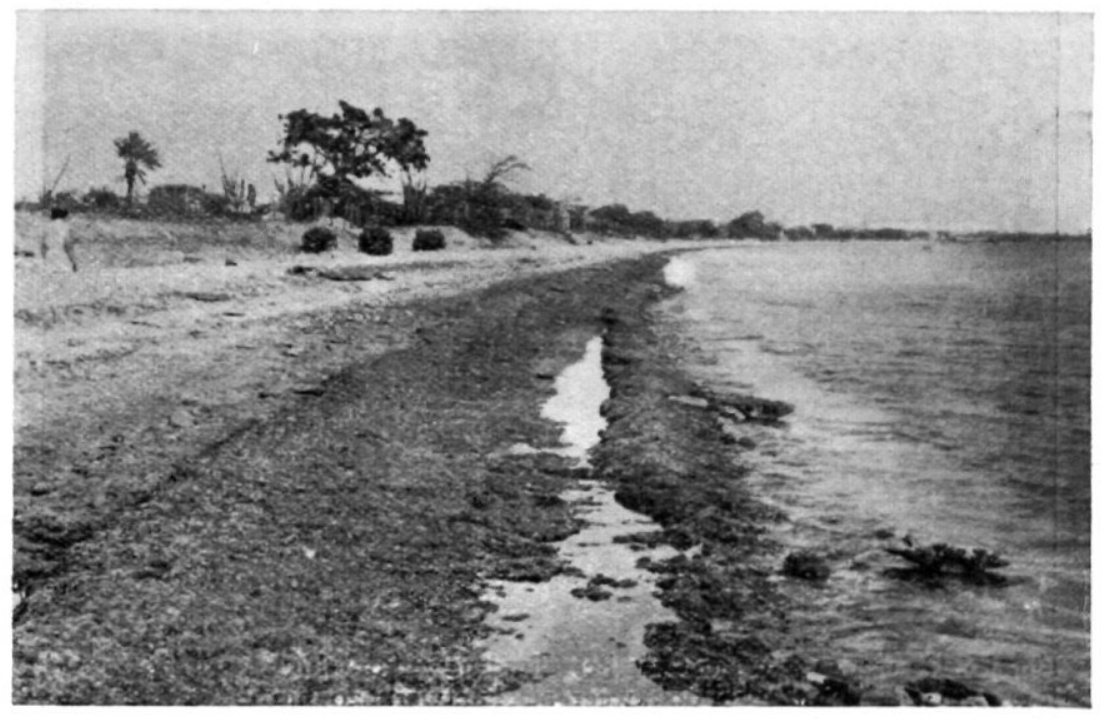

Fig. 14. De kust bij Paloe Lechi, nadat bij laag water de lange drempels zijn drooggevallen (Febr. 1949). 


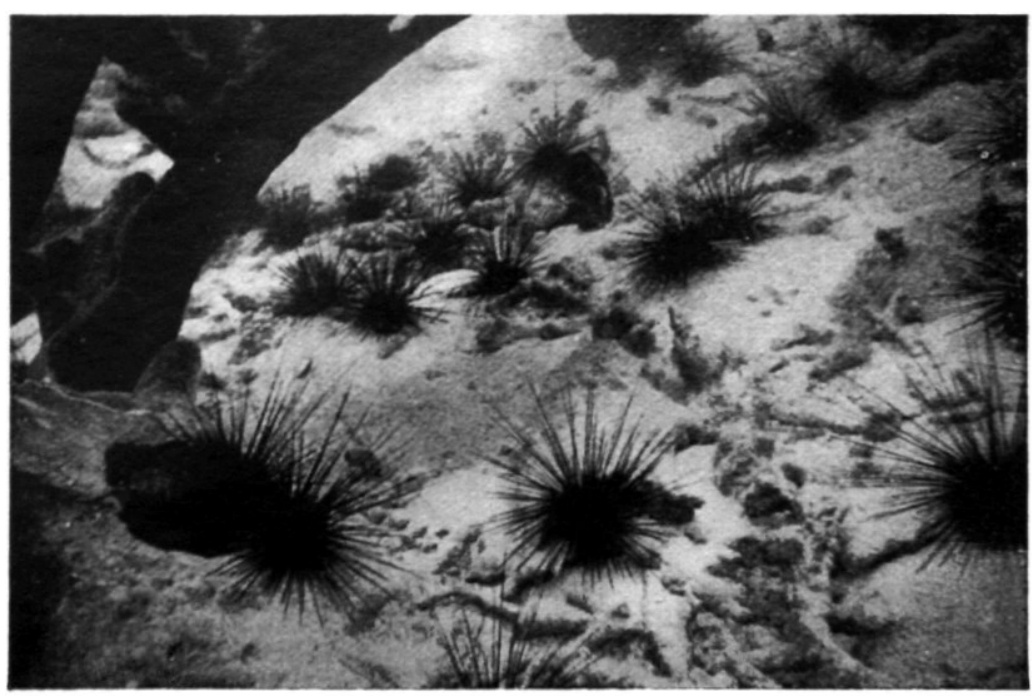

Fig. 15. De gevreesde zwarte zeeappels (Centrechinus antillarum), met hun lange, breekbare stekels, liggen op zandige plekjes onder het elandsgeweikoraal (Noordkust van Klein Bonaire, Oct. 1948).

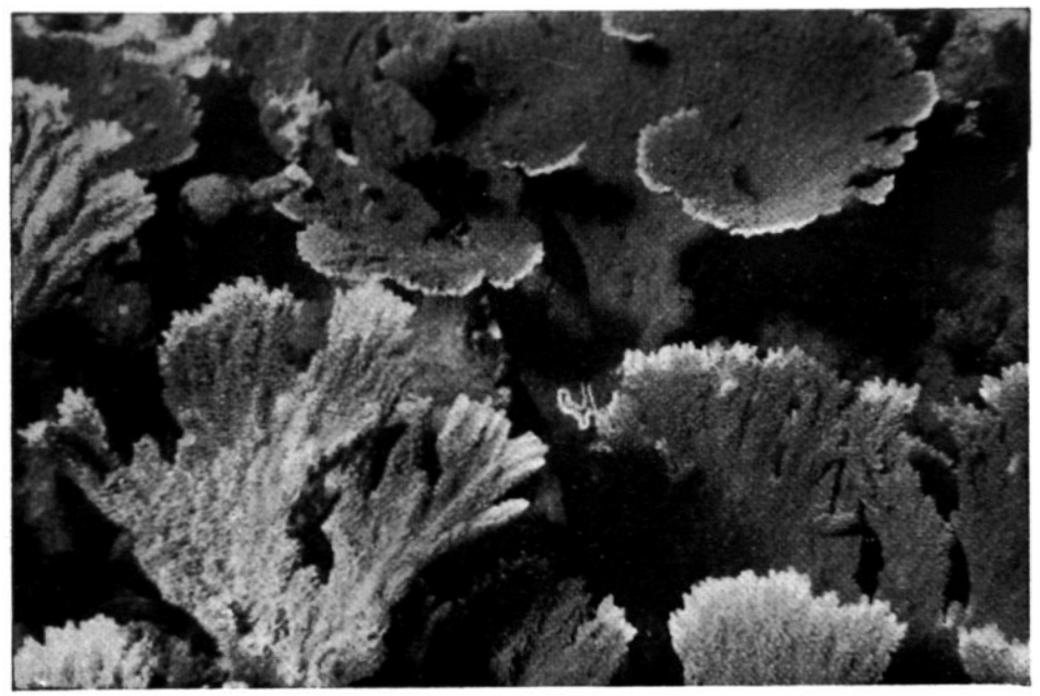

Fig. 16. De machtige waaier van het elandsgeweikoraal (Acropora palmata), fors en sterk, maar toch ook weer als kantwerk zo fijn (Buracu Cachó, Curaçao, Juli 1948). 


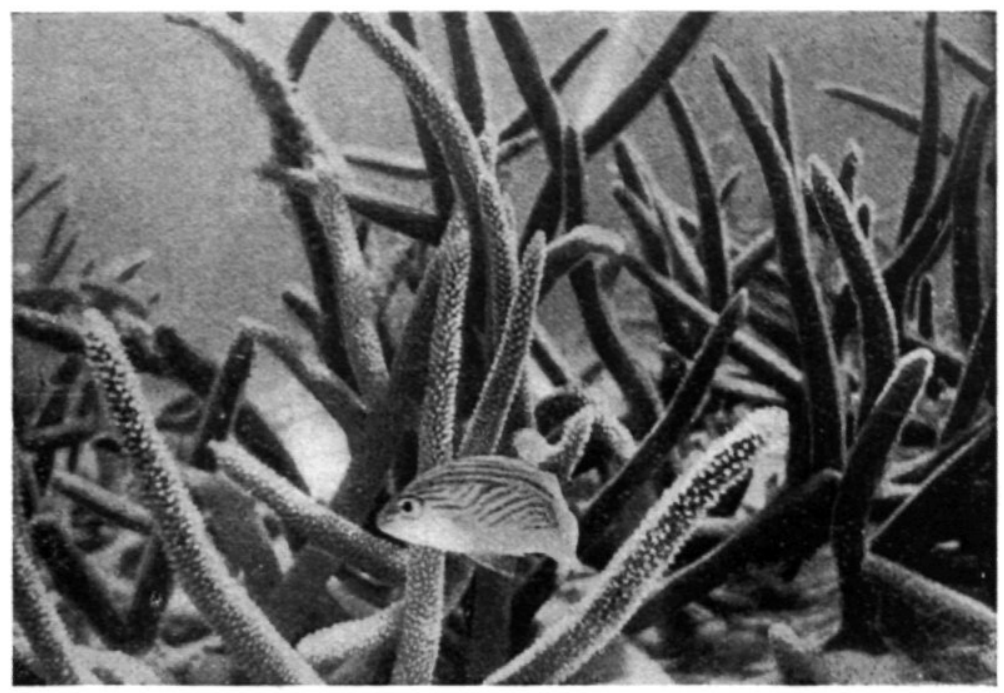

Fig. 17. Een robekkie (Haemulon spec.) op jacht tussen het hertshoornkoraal (Acropora cervicornis) (Kust bij Kralendijk, Bonaire, Oct. 1948).

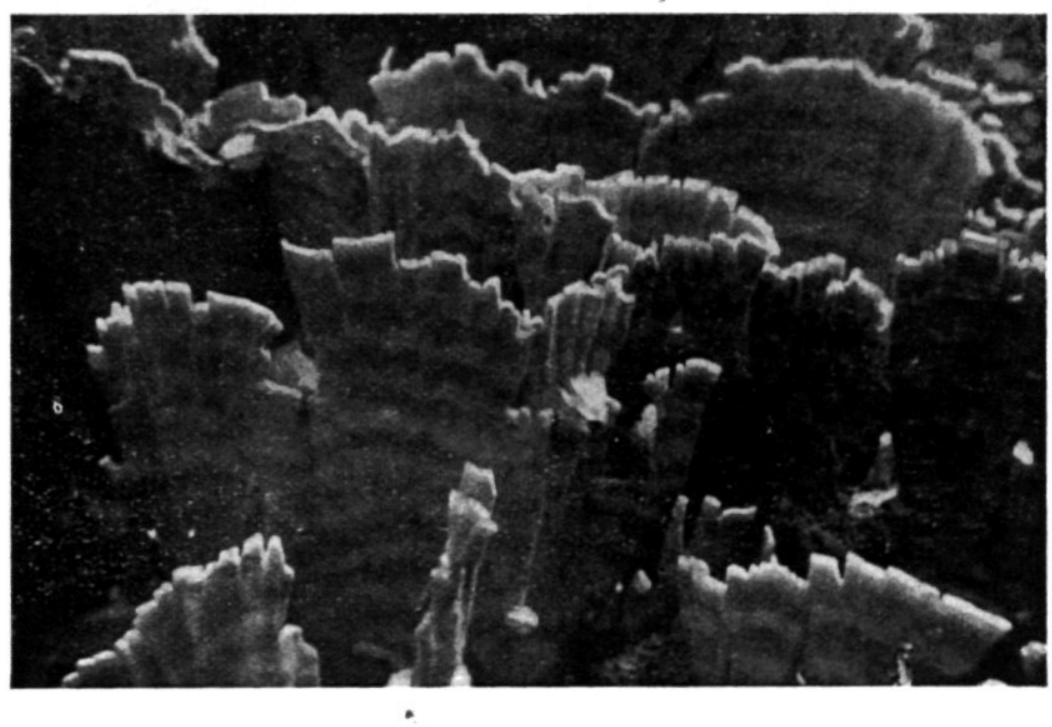

Fig. 18. De sierlijke coulissen van het gevreesde brandkoraal (Millepora complanata) (San Nicolas, Curaçao, Juli 1948). (Fig. 15.18 zijn onderwater-foto's van p. Vitus Brenneker.) 


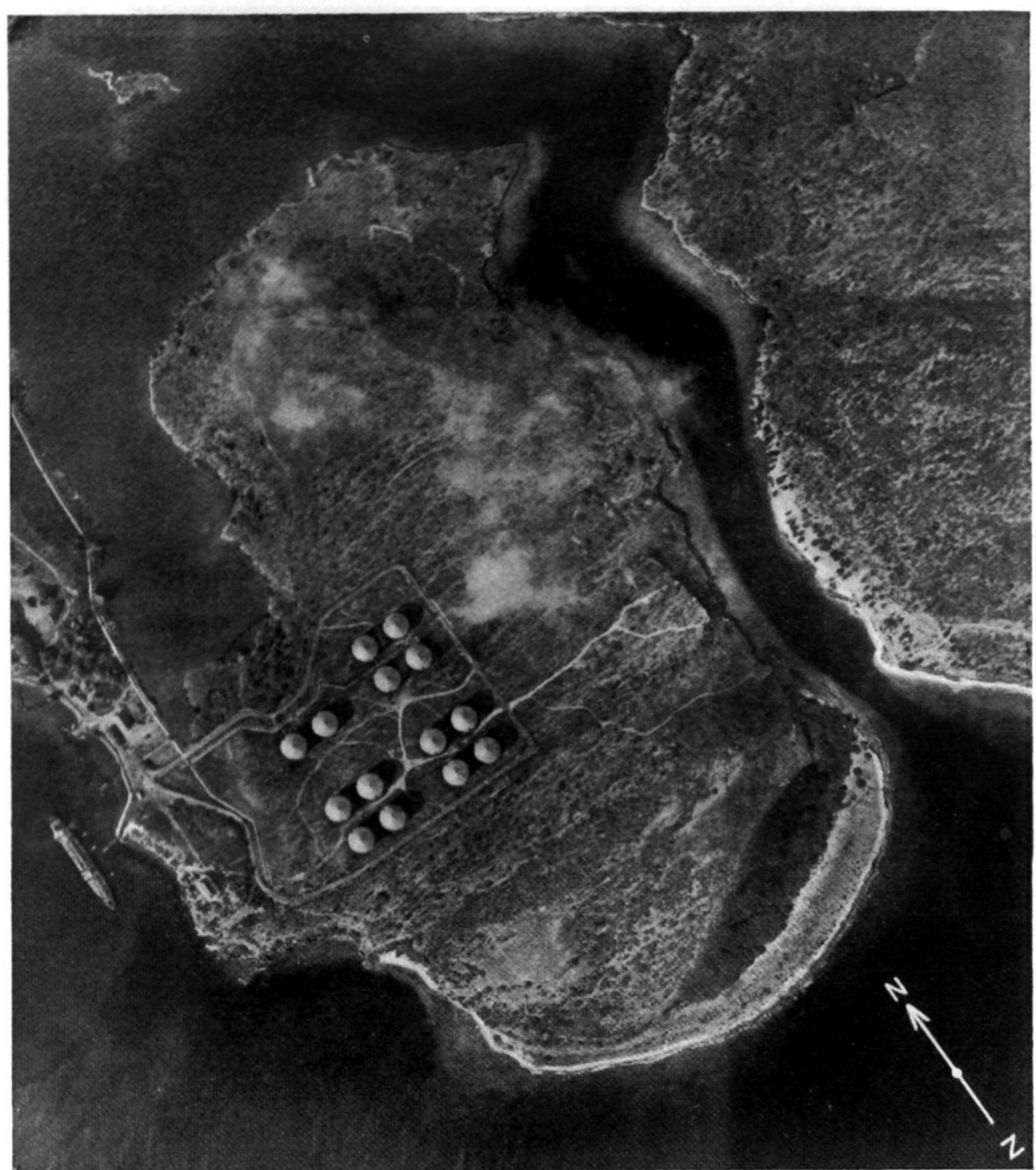

Fig. 19. Luchtfoto van de ingang van het Spaanse Water en de Caracas-Baai. De ondiepe randzones van de ingang van het Spaanse Water zijn lichter gekleurd dan de diepe delen; de witte rand is het zandstrand. In de Caracas-Baai ligt een schip te bunkeren; Zuidoostelijk daarvan ligt het oude Quarantainegebouw; Oostelijk dáárvan olietanks. Ten Westen van de monding een ondiepe lagune met mangroven. Dunne wolkenslierten hebben de Kabrietenberg voor een deel aan het oog onttrokken (Foto K.L.M., 1949). 


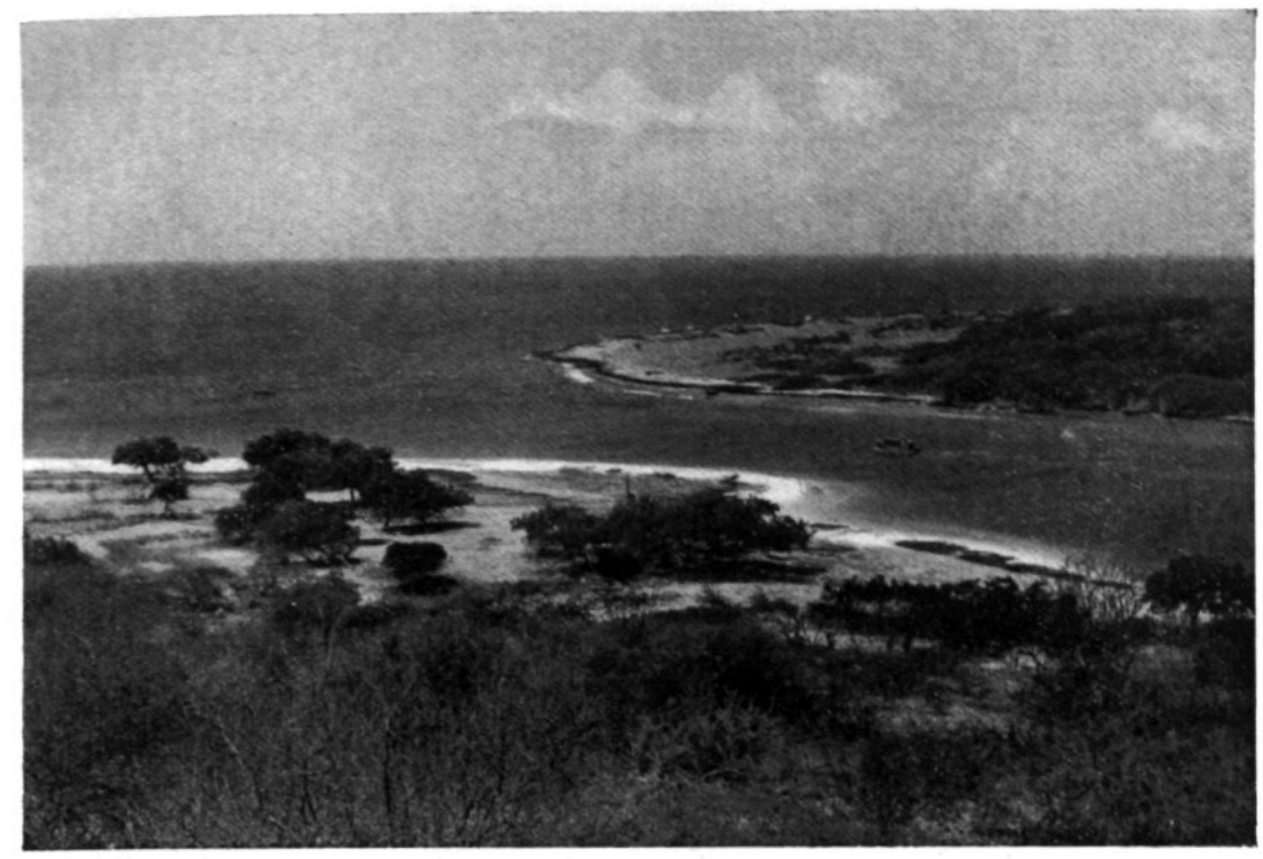

Fig 20. De Boca van het Spaanse Water, naar het Zuid-Zuidwesten gezien (Apr. 1949).

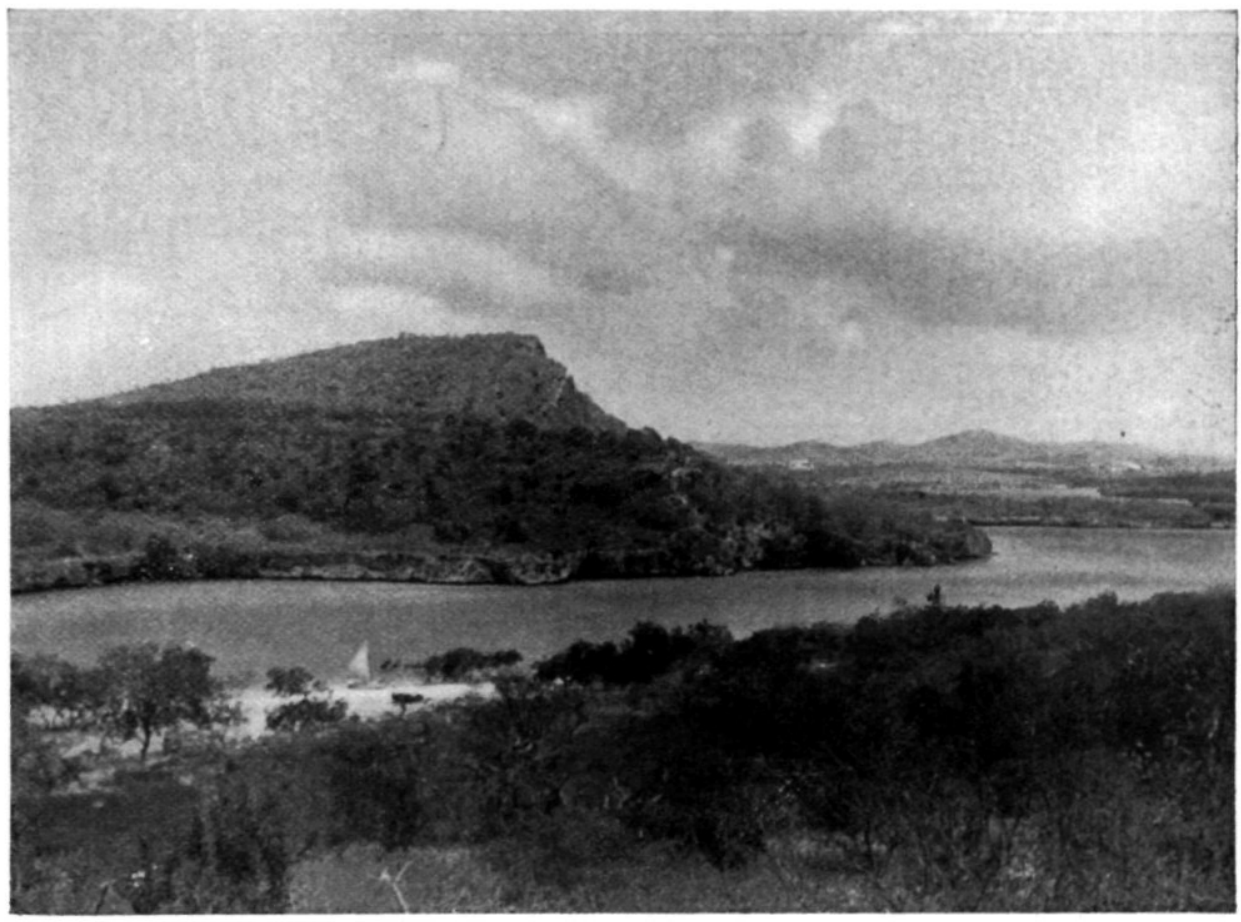

Fig. 21. De ingang van het Spaanse Water, naar het Noord-Noordwesten gezien. De steile heuvel is de Kabrietenberg, bijna 80 meter hoog (Apr. 1949). 


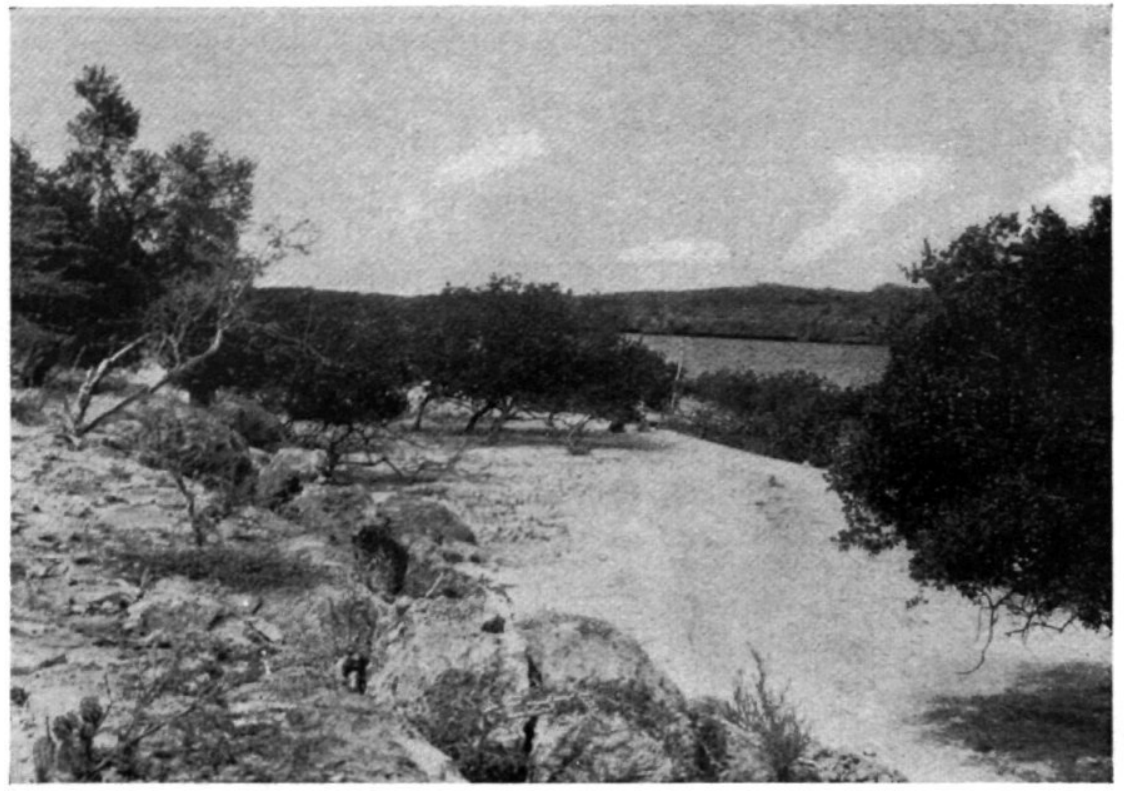

Fig. 22. De Noordelijke uitloper van het zandstrandje aan de ingang van het Spaanse Water, naar het Zuiden gezien. Links de rand van het kalksteenterras; dan volgt een zandstrook met enkele bomen (Conocarpus erecta) en ten slotte enkele kleine, in het water groeiende mangroven (Rhizophora mangle) (Apr. 1949).

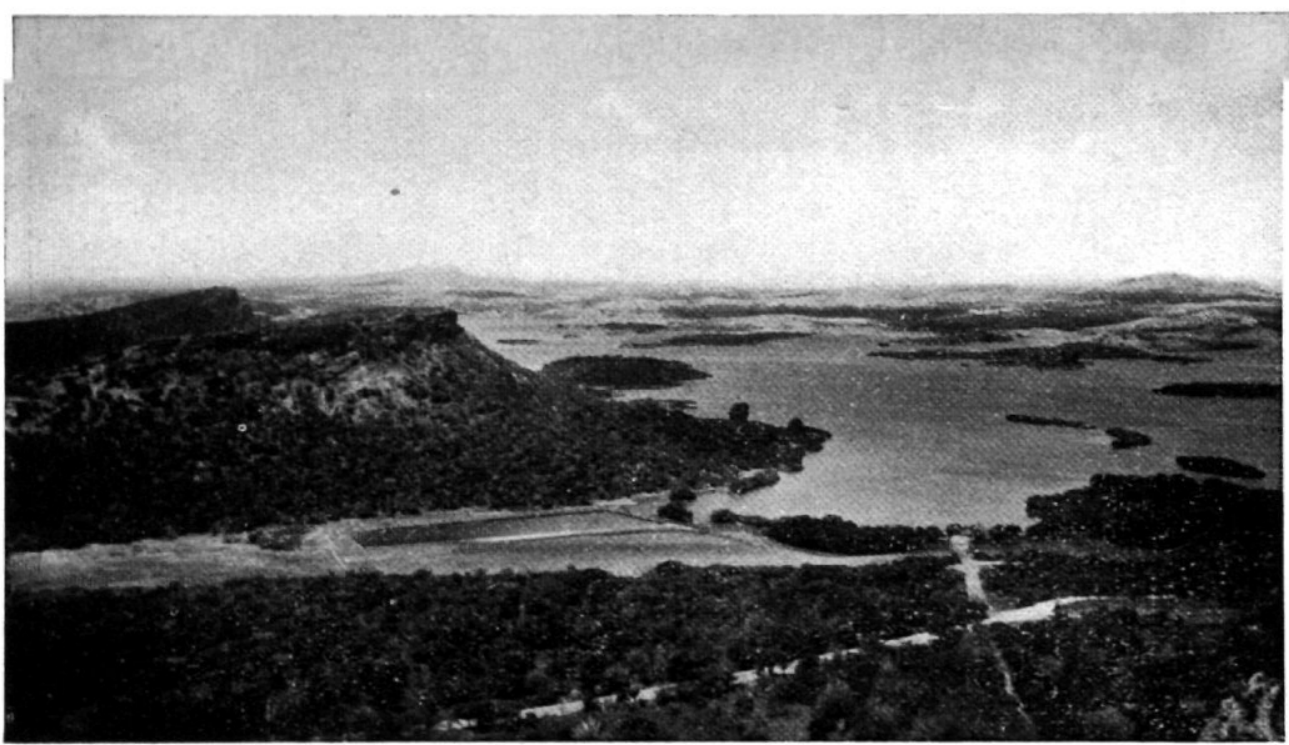

Fig. 23. Uitzicht van de Tafelberg van Santa Barbara over het Spaanse Water. Op de voorgrond de grote weg van Santa Barbara, met de zijweg naar de steiger van New Haven, aan welke baai een verlaten zoutpan is gelegen. Links de toppen van Seroe di Boca en de Kabrietenberg, waartussen het Spaanse Water in zee uitmondt (Foto van dr J. H. W e st e rmann, Febr. 1950). 
één die hen meer „onder de mensen" brengt - zoals het leiding geven aan het werk van natuurliefhebbers, het houden van lezingen, excursies, cursussen en het doen van museumwerk.

De opzet, zoals zij door de „Werkgroep” en de "Studiekring” wordt voorgestaan, beoogt in het kort het uitzenden van één of twee natuurwetenschappelijke onderzoekers per jaar, waarbij het Gouvernement wordt verzocht de reis- en verblijfkosten op de Antillen voor zijn rekening te nemen en de nodige faciliteiten te verlenen.

Door deze regelmatige uitzendingen zal in universitair Nederland tevens hoe langer hoe meer daadwerkelijke belangstelling voor de Antillen ontstaan. En deze is nodig! Want, indien het natuurwetenschappelijk onderzoek niet van alle kanten, op deskundige wijze en behoorlijk gecoördineerd wordt aangepakt, dan zal men zich op de Nederlandse Antillen nog lang moeten behelpen met een moeilijk te gebruiken, verouderde Flora, zal men het nog heel lang moeten doen zònder overzichtelijke zoölogische literatuur en zonder visserij-biologische gegevens, zullen nog vele geologische en bodemkundige vragen van direct belang onbeantwoord blijven, en zal men zich nog vele geldelijke verliezen moeten getroosten, die met iets meer natuurwetenschappelijk inzicht en wat ruimere kennis van de plaatselijke omstandigheden voorkomen hadden kunnen worden.

Het lijkt moeilijk, op dit ogenblik, ons een vorm van samenwerking voor te stellen, waarbij de Nederlandse Antillen op een méér aantrekkelijke en ook meer voordelige wijze het onderzoek van eigen gebied zou kunnen bevorderen.

\section{LITERATUUR}

waarnaar in de tekst werd verwezen,

met bijvoeging van nog enkele algemeen bevattelijk gestelde artikelen.

1827 StifFt, C. B. R.: Geognostische Beschreibung der Insel Aruba .... Curaçao .... Bonaire. - Drie ongepubliceerde rapporten.

1827 ReInwardt, C. G. C.: Waarnemingen aangaande de gesteldheid van den grond van het eiland Aruba .... N. Verhand. $I K l . K$. Nederl. Inst. Wetensch. . I, p. 265-281.

1836 Teenstra, M. D.: De Nederlandsche West-Indische Eilanden .... I. Amsterdam, 351 pp.

1868 Simons, G. J.: Beschrijving van het eiland Curaçou .... Oosterwolde, $156 \mathrm{pp}$.

1871 CleVE, P. T.: On the geology of the North-Eastern West India Islands. K. Svenska Vet. Ak. Handl. 9, 12, 48 pp. 
1885 Martin, K.: De Nederlandsche expeditie naar de West-Indische eilanden en Suriname 1884-1885. Tijdschr. Nederl. Aardr. Gen. (2) 3 Versl., p. 337-361, 448-487, 610-646.

1886 SURINGAR, W. F. R.: Nederlandsch West-Indische Expeditie. Verslag en reisverhaal. Tijdschr. Nederl. Aardr. Gen. (2) 3 Versl., p. 45-90, 355-394, 511-545. - Gaat niet verder dan de eerste dagen op Curaçao. Bibliografie van zijn melocactus-studies en die van zijn zoon, in het Gedenkboek J. Valckenier Suringar der Nederl. Dendrol. Vereen., 1942, p. 88-95.

1886 SNellen, P. C. T.: Bijdrage tot de kennis der Lepidoptera van het eiland Curaçao. Tijdschr. Entom. 30, p. 9-66.

1887 Hasselt, A. W. M. van: Araneae exoticae .... Curaçao, Bonaire et Arubā. Tijdschr. Entom. 3o, p. 227-244.

1886 Molengrafaf, G. A. F.: De geologie van het eiland St. Eustatius. Diss. Utrecht, Leiden, 62 pp.

1887 Lidth de Jeude, Th. W. van: On a collection of reptiles and fishes from the West-Indies. Notes Zool. Mus. Leyden 9, p. 129-139.

1888 Martin, K.: Bericht über eine Reise nach Niederländisch WestIndien .... I Land und Leute, 186 pp. II Geologie, 238 pp. Leiden.

1891 Breda de HAAn, Jacob van: Anatomie van het geslacht Melocactus. Diss. Leiden, 123 pp.

1891 Hurtado, C.: Compendio di botanica elemental.

1893 HARTERT, ERNST: On the birds of the islands of Aruba, Curaçao and Bonaire. Ibis (6) I9, p. 289-338. - Zijn reisverhaal verscheen pas in 1902, Novit. Zool. 9, p. 273-309.

1902 WeNt, F. A. F. C.: Rapport omtrent den toestand van land-en ooftbouw op de Nederlandsche Antillen. Bijlage Kol. Versl. Curaçao, 71 pp.

1907 Rijkens, R. H.: Curafao. Verbetering van den landbouw aldaar ... Tiel, 139 pp.

1907 Вовке, J.: Rapport betreffende .... de visscherij en de industrie van zeeproducten in de Kolonie Curaçao. I. 's-Gravenhage, 200 pp. - Deel $I I, 1919$, bevat in hoofdzaak de bewerking van de verzamelde vissen.

1909 Cory, Charles B.: The birds of the Leeward Islands, Caribbean Sea. Publ. Field Mus. Nat. Hist. 137, Ornith. Ser. 1, p. 192-255.

1909 Nijman, H. J.: Beknopte aardrijkskunde der Kolonie Curaçao. Amsterdam, 56 pp.

1909 Boldingh, I.: The flora of St. Eustatius, Saba and St. Martin. Leiden, 231 pp. Ook als diss. Utrecht.

1911 Topographische kaart van Curaçao, I : 20.00o. ('s-Gravenhage), 18 bladen. - Die van Aruba, 8 bl., verscheen in 1912, die van Bonaire, 10 bl., in 1916. St. Martin 2 bl., St. Eustatius 1 bl.

1913 Boldingh, I.: Flora voor de Nederlandsch West-Indische Eilanden. Amsterdam, $450 \mathrm{pp}$.

1914 Boldingh, I.: The flora of Curaf̧ao, Aruba and Bonaire. Leiden, 197 pp.

1914 Vernhout, J. H.: The land- and freshwater-molluscs of the Dutch West-Indian Islands. Notes Zool. Mus. Leyden 36, p. 177-189.

1914 Barbour, Thomas: A contribution to the zoögeography of the 
West Indies, with especial reference to amphibians and reptiles. Mem. Mus. Comp. Zool. Harvard 44, p. 209-359.

1914-1917 Encyclopaedie van Nederlandsch West-Indië. 's-Gravenhage, 782 pp. (1915 p. 321-512; 1916 p. 513-768).

1919 Metzelaar, J.: Report on the fishes .... in the Dutch West Indies .... BОЕке, Rapport visscherij Curaçao II, p. 1-135. Ook als diss. Over tropisch Atlantisch vissen.

1924 Horst, C. J. VAN DER: Narrative of the voyage .... Bijdr. Dierk. 23, p. 1-12. - Afl. 23, 24 en 25 bevatten uitsluitend bewerkingen van door hem verzameld materiaal onder de boventitel: Bijdragen tot de kennis der fauna van Curaçao. Resultaten eener reis van dr. C. J. van der Horst in 1920; zie ook afl. 22 (reptielen, weekdieren, krabben en kreeftjes, wormen, sponzen e.a.).

1924 BAKER, HorAce BURRINGTON: Land and freshwater molluscs of the Dutch Leeward Islands. Occ. Papers Mus. Zool. Michigan 152, $159 \mathrm{pp}$.

1925 Werner, F.: Zur Kenttniss der Fauna der Insel Bonaire .... Ztschr. Wiss. Zool. I25, p. 533-556.

1926 Winkler, O.: Niederländisch-Westindien. Mitt. Ges. Erdkunde Leipzig 1923-1925, p. 87-137.

1929 Realino, Fr. M.: Aardrijkskunde. De eilanden van Nederlandsch West-Indië .... Curaçao, $120 \mathrm{pp},-2 \mathrm{e}$ herz. druk, Onze eilanden in Nederlandsch West-Indië ...., 170 pp. in 1931; 3e herz. druk De Nederlandse Antillen ...., 214 pp., in 1938.

1929 MolengraAfF, G. J. H.: Geologie en geohydrologie van het eiland Curaçao. Diss. Delft, 126 pp.

1931 Rutten, M. G.: Over de vogels van de Hollandsche Benedenwindsche Eilanden (Antillen). Ardea 20, p. 91-143.

1931 Molengrafff, G. J. H.: Curaçao. Leidsche Geol. Meded. 5, p. 673-689.

1931 Rutten, L. M. R.: Een geologische reis met Utrechtsche studenten naar de Nederlandsche Benedenwindsche Eilanden. W.I. Gids jrg. 13, p. 289-309.

1931 Rutten, L. M. R.: Our palaeontological knowledge of the Netherlands West Indies in 1930. Leidsche Geol. Meded. 5, p. 651-672.

1931 Molengraaff, G. A. F.: Saba, St. Eustatius (Statia) and St. Martin. Leidsche Geol. Meded. 5, p. 715-739.

1932 Rutten, L. M. R.: De geologische geschiedenis der drie Nederlandsche Benedenwindsche Eilanden. W.I.Gids jrg. I3, p. 401-441.

1932 Rutten, M. G. \& Vermunt, L. W. J.: The Seroe di Cueba limestone from Curaçoa. Proc. K. Akad. Wetensch. Amsterdam 35 , p. $228-240$.

1932 MacGillavry, H. J.: The rudist fauna of Seroe Teintje limestone .... Proc. K. Akad. Wetensch. Amsterdam 35, p. 381-392.

1932 Westermann, J. H.: The geology of Aruba. Geogr. Geol. Meded. Utrecht, Phys. Geol. 7, 129 pp. Ook als diss. Utrecht.

1932 Meijer, Adriana S. C.: Bijdrage tot de kennis der volksgeneeskruiden van Nederlandsch West-Indië. Diss. Utrecht, 77 pp.

1933 Wagenaar Hummelinck, P.: Reisebericht. Zool. Jahrb. Syst. 64 , p. $289-326$. - Afl. $3 / 5$ van deel 64 en $5 / 6$ van 67 bevatten 
uitsluitend ,Zoologische Ergebnisse einer Reise nach Boncute, Curaçao und Aruba im Jahre 1930" (w.o. artikelen over de zoetwaterfauna, kwallen, kreeften en krabben en mijten); verder in Mém. Musée Hist. Nat. Belg. (2) 2 en Capita Zool. 8, afl. I, 3 en 4 (hydroïden, naaktslakken, inktvissen, stekelhuidigen e.a.).

1933 PIJ PERS, P. J.: Geology and paleontology of Bonaire (D.W.I .) Geogr. Geol. Meded. Utrecht, Phys. Geol. 8, 103 pp. Ook als diss. Utrecht.

1934 Westermann, J. H.: Schets van de geologische geschiedenis van Curaçao, Aruba en Bonaire. Natuur en Mensch 54, p. 47-53, $147-152$.

1935 BraAk, C.: Het klimaat van Nederlandsch West-Indië. Meded. Verhand. Nederl. Meteor. Inst. 36, 120 pp. - Ook Engelse tekst.

1935 Realino, Fr. M.: Plantkunde van Curaçao voor M.U.L.O. Curaçao, 133 pp. - 2e herz. druk in 1947, 188 pp.

1938 Kruythoff, S. J.: The Netherlands Windward Islands .... A handbook of useful information for visitor as well as resident. (Gedrukt in Antigua), 1938. - 2e druk in 1939, $164 \mathrm{pp}$.

1938 Gabriel, Alfons: Tschogogo. Aus dem Leben der Flamingos. Stuttgart, $56 \mathrm{pp}$.

1936 Wagenaar Hummelinck, P.: Notes on Agave in Aruba, Curaçao, Bonaire .... Recueil Trav. Botan. Néerl. 33, p. 223-249. - Zie ook 35,1938 p. $14-28$.

1938 WagenaAr Hummelinck, P.: Notes on the Cactaceae of Curaçao, Aruba, Bonaire .... Recueil Trav. Botan. Néerl. 35, p. 29-55. - Zie ook Succulenta I6, 1934, 20, 1938 en 22, 1940.

1939 Danforth, Stuart T.: The birds of Saba. Journal Agric. Puerto Rico 22, p. 503-512.

1940 Harders, C. L.: Bijdrage tot de kennis van de Curaçao-aloë en van hare opsporing. Diss. Leiden, 200 pp.

1940 Wagenaar Hummelinck, P.: Studies on the fauna of Curaf̧a, Aruba, Bonaive and the Venezuelan islands. Diss. Utrecht, 130 pp. - Ook uitgegeven als deel $I$ van het gelijknamige seriewerk waarvan met medewerking van specialisten deel 2 verscheen in 1940 en 3 in 1948 (zoogdieren, hagedissen, slangen, kikvorsen, landslakken, mieren e.a.).

1941 Frémy, P.: Cyanophycées des îles Bonaire, Curaçao et Aruba .... Revue Algol. 12, p. 101-152.

1941 Hass, Hans: Unter Korallen und Haien. Abenteuer in der Karibischen See. Berlin, 190 pp. - Zie ook Drei Jager auf dem Meeresgrund, Zürich, 1947, 323 pp., waarnaar Jagers op de zeebodem, Amsterdam, 1949, 288 pp., en Fotojagd am Meeresgrund, Harzburg, 1942, 219 pp.

1943 WagenaAR HumMelinck, P.: Zoögeografische opmerkingen over de Nederlandsche Benedenwindsche Eilanden. W.I.Gids jrg. 25 , p. $168-180$.

1943 WagenaAr Hummelinck, P.: Over grotten en grottenvorming op Curaçao, Aruba en Bonaire. W.I.Gids jrg. 25, p. 365-375.

1943 Amshoff, G. J. H.: The grasses of the Dutch West Indian Islands. Meded. Kol. Inst. 59, Handelsmus. 25, 64 pp.

1945 Breedveld, G. J. F. \& Groenhof, J. P.: Rapport van de Gouvernements. Aloë-Commissie 1942-1943. Curaçao, 86 pp. gestencild. 
1945 TIlburg, Fr. van (Andreas Corsini): Dierkunde op de lagere school. Curaçao, 32 pp. gestencild.

1945 Tilburg, Frater van (Arnoldo Broeders): Onze cactussen. Lux 3. p. $123-141$.

1945 Hamilton, R.: Bijdrage tot de bodemkundige kennis van (Nederlandsch) West-Indië. Diss. Utrecht, 55 pp. - Met kleine toevoeging ook uitgegeven als Meded. Kol. Inst. Handelsmus. 29, met Wa. M. Sesseler als tweede auteur.

1946 Venlo, Frans VAN (p. Vitus Brenneker): Vis met de vissen. Curaçao, 72 pp. - Schetsen overgedrukt uit de Amigoe di Curaçao.

1946 Rapport en notulen van de Commissie ingesteld .... ter bestudeering van het grondwaterprobleem op Curaçao. Curaçao, 58 pp., gestencild. - Het Rapport van de z.g. Watercommissie-RADULPHUS.

1946 Jaarboek 1945-1946. Natuurwetenschappelijke Studiekring voor Suriname en Curaçao, Utrecht, 87 pp. - Jaarboek 1946-1948, 1948, 97 pp. Hierin ook wetenschappelijke bijdragen, met bibliografieën en artikelen over natuurbescherming.

1947 Westermann, J. H.: Natuurbescherming op de Nederlandsche Antillen .... W.I.Gids jrg. 28, p. 193-216.

1947 Hartz, Ph. H., Рot, A. W., e.a. Zie: Medisch werk op Curaçao in 1939-1946. W.I.Gids jrg. 28, p. 329-334.

1948 Jong, M. DE: De vogels van Curaçao, Aruba en Bonaire. Limosa $2 I$, p. 1-9. - Van dezelfde schrijver talrijke artikeltjes in de Beurs- en Nieuwsberichten en andere Curaçaose bladen, 19401945, onder de schuilnaam Vogelvriend.

1948 WagenaAr Hummelinck, P.: Een luchtreiziger over het landschap van de Nederlandse Benedenwindse Eilanden. Tijdschr. Nederl. Aardr. Gen. 65, p. 683-691.

1948 Phelps, William H. \& Phelps Jr., William H.: Two new subspecies of birds from Bonaire Island. Proc. Biol. Soc. Washington 61, p. 171-174. - Zie ook hun Lista de las aves de Venezuela .... I, Caracas, 1950, 427 pp.

1948 Schaub, H. P.: Geological observations on Curaçao, N.W.I. Bull. Amer. Ass. Petr. Geol. 32, p. 1275-1291.

1949 De waterhuishouding van Curaçao en Aruba. ('s-Gravenhage, 192 pp.) gestencild. - Het z.g. Rapport-KrUL, bevattende KRUL, W. F. J. M.: Rapport inzake de waterhuishouding ..., 43 pp.; VISSER, W. C.: Beschouwingen over de regenval, 8 pp., en Nota betreffende de landbouw ...., 56 pp.; SAnting, G.: Nota inzake de hydrologie ..., 85 pp. Samengevat in de W.I.Gids jrg. 31 , 1950 , p. $21-42$.

1949 Westermann, J. H.: Overzicht van de geologische en mijnbouwkundige kennis der Nederlandse Antillen, benevens voorstellen voor verdere exploratie. Meded. Ind. Inst. 85, Trop. Prod. 35, 168 pp.

1950 WagenaAr Hummelinck, P.: Biologische belangstelling voor de Nederlandse Antillert. Vakblad voor Biologen 3o, p. 133-142. Hierin ook over het museum (zie Beurs Nwsber. 11 Jan. 1949, p. 3 en 13 Sept. 1949 , p. 3, en vooral ook Bijlage van 8 Apr. 1950, p. 2-3) en het biologisch station (zie Beurs Nwsber. 19 Oct. 1948, p. 1 en ook 11 Jan. 1949 , p. 3 en 13 Sept. 1949, p. 3).

1950 Venlo, Paul van (p. Vitus Brenneker): Met de camera op de zee- 
bodem van Curaçao. Privé uitgave, gedrukt in Hilversum (in Nederland verkrijgbaar bij Studio Dré Brenneker, Venlo), 63 pp. waarvan 3-4 met tekst en 5-63 met 64 foto's met korte onderschriften.

\section{SUMMARY}

Herfst 1950.

\section{Scientific interests in the Netherlands Antilles}

The opinion that the Netherlands Antilles would be islands more or less neglected by Mother Nature seems to be a thing of the past. In recent years - since our knowledge of geology, geohydrology, and general ecology has greatly developed and the study of flora and fauna has yielded satisfactory results - the Netherlands Antilles, and especially Curaçao, Bonaire and Aruba, have proved to be a nature paradise for both scientists and amateurs.

Scientific research (p. 2-8, p. 25-30)

During the Dutch expedition, which visited the Islands in 1885, a geological survey was carried out by professor K. MARTIN and one of his students, G. A. F. MolengraAfF; botanical work was done by W. F. R. Suringar. ERnst Hartert produced the first ornithological publication in 1893. In $1905 \mathrm{~J}$. BoEKE made the first extensive collection of fishes.

I. Boldingh composed the well-known Flora's, of which until now, almost forty years later, no revised edition has been published. The topographic map 1:20,000, prepared between 1906 and 1912, is of high quality but needs to be modernized. The preparation of an up to date photogrammetric map is held up by lack of finances. As the Encyclopaedia of the Netherlands West Indies does not go beyond our knowledge of 1915, plans are being made for composing a new encyclopaedia.

The scientific results of the collections made in 1929 by C. J. vaN DER HORST are an important contribution to our knowledge of the fauna of the Southern Caribbean area. H. BURrington BAKER made an intensive study of the land mollusks of the Dutch Leeward Islands, from which he drew valuable zoogeographical conclusions.

The geological studies on Curaçao by G. J. H. MolengraffF were followed by geological researches in 1930, by L. M. R. Rutten and some of his students. Two monographs - one on Aruba by J. H. WesTERMANN and one on Bonaire by P. J. PIJPERS - and a number of smaller papers were the result of this expedition. Since then additional geological investigations were carried out. A detailed survey of our knowledge of geology and mining was given recently by J. H. WESTERmanN, 1949. The publication of R. A. Christman's reconnaissence of St. Martin is soon to be expected.

Of the abundant faunistic material collected by P. WAGENAAR HUMMELINCK in 1930,1936-'37, and 1948-'49, so far only parts have been sorted out and described with the aid of specialists.

Scientific interest organised (p. 8-9)

Scientific interest concerning the Netherlands Antilles is at present organised in the ,Natuurwetenschappelijke Studiekring voor Suriname en Curaçao" (Foundation for Scientific Research in Surinam and the Netherlands Antilles) which was established at Utrecht on August 
29th, 1945. On 27 December 1948 the ,Natuurwetenschappelijke Werkgroep Nederlandse Antillen" (Natural Sciences Study Group Netherlands Antilles) was founded on Curaçao; it has already held several meetings and excursions. These two bodies, which cover much common ground, work in close cooperation. The Study Group also works together with the Curaçao Museum.

Scientific Museum (p. 9-16)

The Curaçao Museum was opened on March 7th, 1948, in a previous military hospital, which by well-planned reconditioning was turned into an attractive museum (fig. 1 and 9). The greater part of the ground floor (fig. 3) is intended for exhibition of biological and geological specimens (fig. 4). But many more provisions have to be made, before the people of Curaçao can have the full benefit of the Museum. A first requirement is the appointment of a full-time director who will give guidance in all museum activities and who will see to it that the collections are used to their full educational, scientific and aesthetic possibilities.

Biological Station? (p. 16-24)

One of the projects of the Foundation for Scientific Research is the establishment of a marine biological station. It is suggested that this station should have a small permanent staff and promote exchange of scientists. The Lerner Marine Laboratory at Bimini, in the Bahamas (p. 17-20, fig. 5-7, 10-12), is a good example of a biological station in the Caribbean; a similar institute in the Netherlands Antilles, however, should differ from this in several essential points.

The coast near Kralendijk, on Bonaire, seems an attractive locality for the establishment of such a marine biological station. On Curaçao, however, special interest was shown for the building of an aquarium which would attract biologists as well as tourists. In such an aquarium the water circulation could be brought about by the natural water current and the tide. The fauna and flora of the tanks accordingly would live under almost natural conditions, and should be observed and studied from a passage below water level.

Under present financial conditions construction and exploitation of a show-aquarium of this type is possible only on Curaçao. Consequently the biological station should be built also on this island, as its personnel would run the aquarium. The obvious locality for this project is the entrance of the Spanish Water (fig. 8, 19-23). Moreover, this entrance, and the neighbouring land area appear to be a suitable site for a National Park (fig. 8).

Other scheme of research (p. 24-25)

The Foundation and Study Group are in favour of a scheme of research which is inexpensive and adapted to the present circumstances. This aims at sénding out advanced Netherlands students or qualified biologists to do research work in the Netherlands Antilles. Apart from their specialist work these scientists also have a wider task: the establishing of cultural contact with the inhabitants, that these may reap some direct benefit from the visits of their overseas guests. 